\title{
Mining's contribution to national economies between 1996 and 2016
}

\author{
Magnus Ericsson ${ }^{1}$ (D) Olof Löf $^{2}$
}

Received: 4 December 2018 / Accepted: 9 May 2019 / Published online: 12 June 2019

(C) The Author(s) 2019

\begin{abstract}
In several low- and middle-income countries rich in non-fuel mineral resources, mining makes significant contributions to national economic development as measured by the revised Mining Contribution Index (MCI-Wr). Ten countries among the 20 countries where mining contributes most (highest MCI-Wr score) have moved up one or two steps in the World Bank's country classification between 1996 and 2016. In particular, African countries have benefitted. Socioeconomic development indicators also show signs of progress for African mineral-rich countries. This paper provides an update and expansion of an earlier study within the framework of the United Nations University (UNU) World Institute for Development Economics Research (WIDER) initiative Extractives for Development. Based on the detailed data available for the sector, such as production, export, prices, mineral rents, exploration expenditure and government revenues, an analysis is carried out of the current situation for 2016, and trends in mining's contribution to economic development for the years 1996-2016. The contribution of minerals and mining to GDP and exports reached a maximum at the peak of the mining boom in 2011. Naturally, the figures for mining's contribution had declined for most countries by 2016 , but importantly the levels were still considerably higher than in 1996 . The results of this survey contradict the widespread view that mineral resources create a dependency that might not be conducive to economic and social development. In addition, this paper presents an attempt to use already available socio-economic indicators for African mineral-rich countries to measure socio-economic developments. One preliminary conclusion of this survey is that mining countries perform better than oil-producing countries and non-mineral countries in Africa as measured by these indices of human development and governance.
\end{abstract}

Keywords Extractive industries $\cdot$ Mining contribution $\cdot$ Mineral rent $\cdot$ Africa $\cdot$ "Super cycle" $\cdot$ Mineral export $\cdot$ Exploration $\cdot$ Mine production

\section{Introduction}

This paper is an updated and expanded version of a presentation given at the XVth Dundee Mining Seminar held on 5/6 April 2017. ${ }^{1}$ The presentation was based on the study Mining's contribution to national economies that was initiated

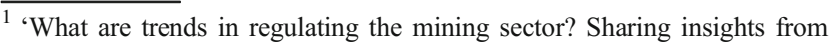
research and practice', organised by the Centre for Energy, Petroleum and Mineral Law and Policy, Luleå University of Technology and Bundesanstalt für Geowissenschate und Rohstoffe.
}

Magnus Ericsson

magnus@gladtjarnen.se

1 Luleå University of Technology, Luleå, Sweden

2 RMG Consulting, Stockholm, Sweden by UNU-Wider in Helsinki, which was later developed into a chapter in the book Extractive Industries: The Management of Resources as a Driver of Sustainable Development. ${ }^{2}$ The UNU-Wider report attempts to explain and document how 'minerals dependency' has changed in the past 20 years on a country-by-country level. In the present paper, the time series is updated to 2016 and a discussion is added of the development of some socio-economic indicators.

Based on available detailed data for the minerals and metals sector in as many countries as possible, an analysis is carried out of the current situation for 2016 compared with 2014, and how the contribution by mining to economic development has changed since 1996 . The study covers all non-fuel minerals and coal for short in the text called metals and

\footnotetext{
${ }^{2}$ Addison, Tony and Alan R. Roe. 'Extractive Industries: The Management of Resources as a Driver of Sustainable Development', Oxford University Press, 2018.
} 
minerals. Oil and gas are excluded. Economic data have been gathered for production, prices, mineral rents, exploration expenditure and government revenues, and added to this the following socio-economic indicators: Human Development Index, various governance indicators and the Governance and Inequality (the GINI coefficient). The focus is on the following questions:

- How much do the mining industries statistically contribute to national economies?

- Has the level of contribution changed as a result of the sharp drop in the prices of most extracted commodities since about 2011-after the end of the so-called 'super cycle'?

- How has that level of statistical contribution changed over the past 20 years from 1996 to 2016 ?

- How have socio-economic indicators developed in the same period in African mineral resource rich countries?

The paper covers all countries but low- and middle-income developing economies are given additional attention to follow up on our earlier study. ${ }^{3}$ Our intention is to collect and analyse statistical data on a global level over a long period of time and to give an empirical contribution to the discussion about the role of mineral resources in economic and social development of countries. The purpose of the paper is not to provide a full analysis of all the factors behind the observed changes in economic and social contribution by mining. We hope our data and analysis can give inspiration and direction for additional research to perform such analyses.

The paper starts with a methodological discussion and proceeds with the first question raised above: a review of the Mining Contribution Index (MCI-Wr) in 2016 compared with 2014. The four components of the MCI-Wr are the following: value of mine production, mineral exports, exploration and mineral rents. They are presented and analysed together with other factors affecting mining's contribution. A discussion of the second and third question follows: changes in contribution over time both since 2014 and over the entire period under study. The socio-economic issues are dealt with in the subsequent section. Finally, our conclusions are presented.

\section{Methodology}

In recent years, several approaches to assess the magnitude of the contribution/dependence of countries on extractive resources have been presented. ${ }^{4}$ This study is based on the

\footnotetext{
${ }^{3}$ Ericsson, M. and Löf, O., Mining's contribution to low- and middle-income economies, WIDER Working Paper 2017/148, June 2017.

${ }^{4}$ Hailo, D. and Kipgen, C. 'The Extractive Dependence Index (EDI)', Resources Policy 51, pp. 251-264, 2017.
}

Mining Contribution Index (MCI) that was developed by the ICMM. ${ }^{5}$ A later version called Mining Contribution Index WIDER $^{6}$ (or MCI-W for short) was presented. In this study, the following four economic indicators are used:

- The total production value at mine stage of metallic minerals, industrial minerals and coal expressed as a percentage of GDP (sourced from USGS, BGS, Raw Materials Data, RMG Consulting).

- Exports of minerals including coal as a share of total merchandise exports (sourced from UN Comtrade).

- Exploration expenditure as a percentage of production value at mine stage (sourced from SNL Metals \& Mining, the data was previously presented by Metals Economic Group and lately by S\&P Global but is one continuous time series).

- Mineral rents as a percentage of GDP (sourced from World Bank Data).

The first two indicators have been used in previous studies of mining's contribution to national economies and their inclusion in the index is easily understood. The third and fourth (exploration and mineral rents) warrant some explanation.

Data on exploration expenditure ${ }^{7}$ provides an indication of the likelihood of continued mining activity in a country and hence about the long-term viability and continuity of mining. Without exploration, the mining sector will most likely shrink or even disappear sooner or later, as no new deposits will be found. With exploration, it is more likely that new deposits will be found and the mining sector will grow and hence its contribution will increase. If the mine production in a country, expressed as a percentage of total mine production in the world, is compared with exploration expenditure in the same country also measured relative to global exploration expenditure, it is reasonable to assume that if the relative share of exploration is higher than that of mining, it is likely that mining will grow in the future, and vice versa. In the present version (MCI-Wr), we have chosen to relate the exploration expenditure to the mine production of each country and not as earlier use the absolute size of exploration as the indicator. Our previous model of calculation lead to an overemphasis of this indicator as in all countries exploration expenditures are small compared with the size of mining itself and its economic impact. Exploration expenditure certainly also involves money spent in the country that might generate jobs and add to GDP,

\footnotetext{
${ }_{6}^{5}$ ICMM, The role of mining in national economies, 3rd edition 2016.

${ }^{6}$ Ericsson, Löf, op.cit.

${ }^{7}$ SNL Metals \& Mining's World Exploration Trends focus on corporate spending. In reality, if all metals and minerals would be included, and if all exploration undertaken by all types of entities, not only corporates but also governments, total exploration on both a national or global basis is definitely higher than indicated by SNL. Further, the SNL figures are based on budgeted expenditure and not actual figures. In this study, however, these discrepancies are considered to be of minor importance.
} 
but even if exploration in some regions of a country can provide considerable additions to GDP, this effect is an additional reason for including this indicator in the MCI-Wr. Thirdly, exploration generates additional knowledge of a country's geological potential and thereby adds to its mineral balance sheet.

Mineral rent is the difference between the value of production of a mineral at world prices and the total cost of production including in costs an estimate of the 'normal' return on capital. Minerals for which this indicator is calculated by the World Bank are tin, gold, lead, zinc, iron, copper, nickel, silver, bauxite and phosphate. ${ }^{8}$ Countries where other minerals and metals (coal being the most important one) are produced will get a lower MCI-Wr score as these rents are not included in the calculation. In order to make the mineral rent indicator more useful and get a wider coverage, we have calculated diamond rents using the same formula as the World Bank has done for the other metals. We have not calculated mineral rents for any other minerals or metals than for diamonds. The reason for this single addition to the mineral rent indicator is that among the low- and middle-income countries with high MCI-Wr scores, Angola, Botswana and Namibia are countries where diamond mining is particularly important. Further, we have noticed a second issue with the rent calculations by the World Bank. The mineral rents for some countries are for some years higher or almost as high as the total value of mine production. Could one explanation be that rents are also calculated on the production of metals and semi-products under way to become metal (blister copper and the like)? It is impossible from the statistics to ascertain what the reasons are for these figures. We find however the mineral rent aspect of mining's contribution to be important and chose to include these data in spite of the difficulties mentioned. The effect of these shortcomings in the available statistics is that for some countries, the economic contribution of mining is underestimated.

A number of additional indicators could be used to quantify the economic contribution of mining to national economies such as taxes paid, employment created, investments made and value added by the sector. ${ }^{9}$ All or any of these are important and would shed more light on the issue of mining's contribution to national economies. However, it has not been possible to include these variables for lack of statistics either the geographical coverage has not been sufficient or only a few years of the period under study (1996-2016) are covered. ${ }^{10}$ Our intention is to study a majority of the countries in the world and not only a selection, which has been the most

\footnotetext{
${ }^{8}$ World Bank https://data.worldbank.org/indicator/NY.GDP.MINR.RT.ZS

${ }^{9}$ For an extended discussion see: Hailo, D. and Kipgen, C., op. cit.

${ }^{10}$ The search for employment statistics could serve as but one example of the problems encountered when collecting the necessary statistics.
}

common approach in previous work. Employment is one key factor for which statistics are not available. The Laborsta statistics by the International Labour Office (ILO) is unfortunately not up-to-date and is not covering all important mining countries. In some cases, it is further difficult to separate between employment in the mining sector from oil and gas industries. The Geneva office of the ILO has been reorganised and is lacking resources, which has created additional problems. We have tried to contact national statistical offices in the most important countries with limited success. Other potential global sources of statistics such as the EITI, ICMM and the IndustriAll, the global federation of mining trade unions, have been consulted with only limited success. This area should clearly be one priority in continued research into the contribution of mining to national economies. In 2017, an Extractive Dependence Index (EDI) was developed by UNDP using three variables of which the extractives industry's value added is included as a factor previously not extensively studied. ${ }^{11}$

In addition to mining activities covered by the statistics used in this study, almost all countries have some, often small scale, mining activity producing for example coal and aggregates for domestic use. These mineral products are most often not exported as their low value does not allow transport over any longer distances and hence the contribution to exports is small. They may however contribute considerably to GDP and have important employment effects but due to lack of statistics their contribution is not included in this study. If this production of construction materials and coal for local use and also smallscale production of other minerals and metals, in particular gold and precious and semi-precious stones, not systematically covered in the statistics we have used, is included the contribution of mining to national economies would increase. It is impossible to say how much, but clearly the figures presented show a floor from which the full contribution could grow if better statistics would be available.

The Revised Mining Contribution Index WIDER (MCI$\mathrm{Wr}$ ) is calculated as follows: countries are ranked in descending order for each of the four indicators. Countries for which data do not exist are omitted from the ranking. For each country, percentile ranks are calculated based on the four indicators, by dividing the country rank by the maximum rank within that indicator to generate a ranking between zero and one. Finally, the four MCI indicators are weighted equally at $1 / 4$, summed up, and multiplied by $100 .^{12}$

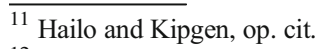

${ }^{12}$ ICMM, The role of mining in national economies 2nd edition 2014.
} 


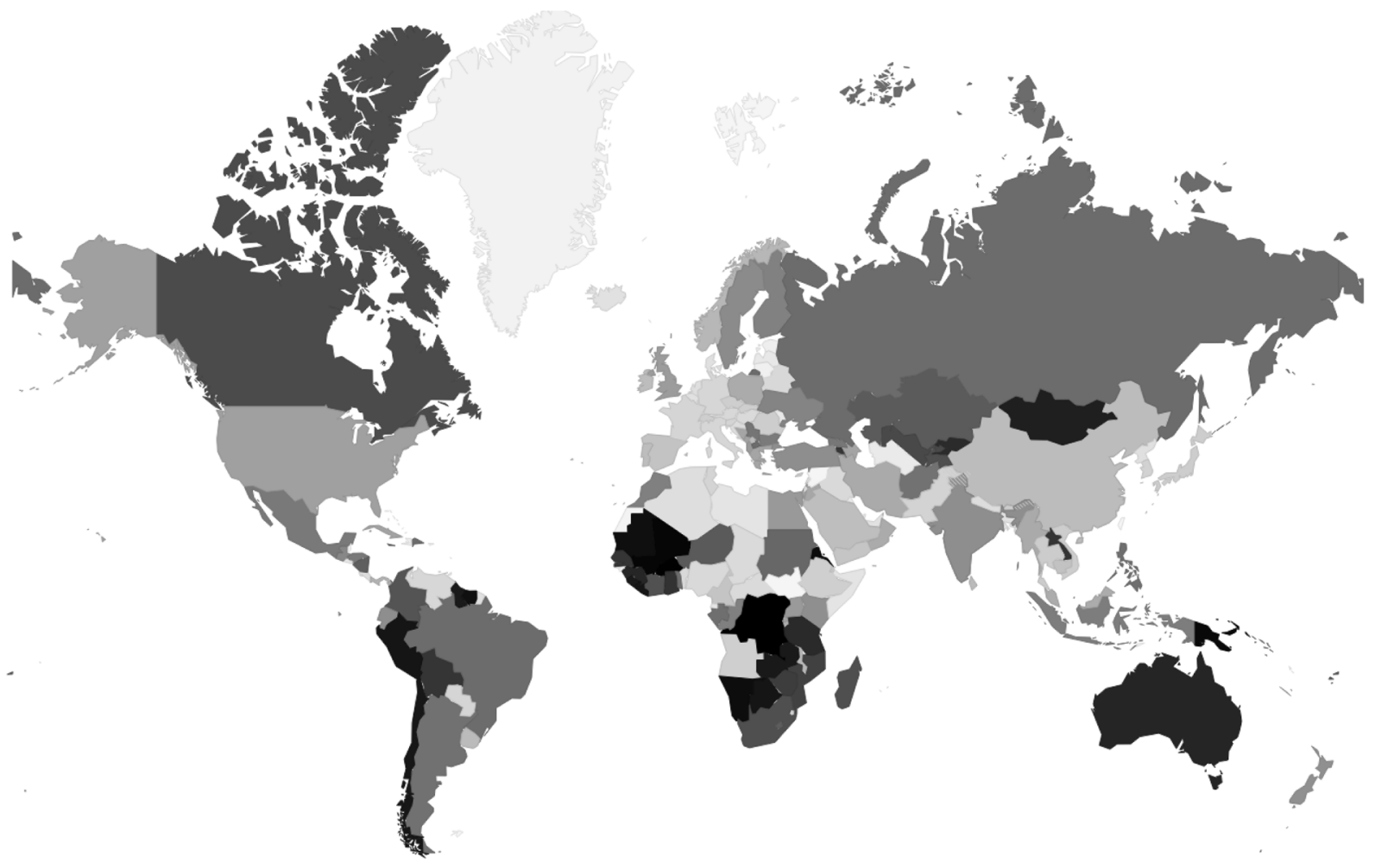

More contribution to wealth

Less contribution to wealth

Fig. 1 Mining contribution index (MCI-Wr) score by country 2016. Source: Own calculations

\section{MCI-Wr 2016-current levels of mining's contribution to national economies}

The 2016 update of the MCI-Wr index confirms that mining is an important part of many nations' economies, and of these countries, a majority is low- and middle-income economies. The map in Fig. 1 shows the countries with the highest levels of contribution in black and those where mining contributes less are in more pale grey towards white indicating no contribution at all. Regions where the contribution of mining is particularly high include Western, Southern and Central Africa, Oceania, Central Asia and Latin America. The regions where mining contributes less to national wealth are Western Europe, the Middle East and North Africa, Japan and some countries in South Asia. Figure 2 shows the MCI-Wr index by country in 1996.

In the present MCI-Wr based on the latest available data for $2016,{ }^{13}$ the Democratic Republic of Congo (DRC) is ranked as the country with the largest contribution of mining to its

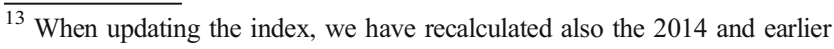
figures. For some countries, they have changed mainly due to the revision of export figures, which is done continuously by the UCTAD. It should also be noted that for some countries, there is no GDP figures for a certain year. We have estimated these figures by using data from another year, either before or after.
}

economy, see Table 1 . Mineral exports constitute $86 \%$ of total exports and the DRC is ranked as the second most important country in relation to mineral export contribution. Mineral production value at the mine stage was 6.8 billion USD in 2016 and the mineral production value as per cent of GDP was $12 \%$ : on this indicator, the DRC is ranked as number two. Exploration expenditure was 143 MUSD in 2016 and expressed as a share of production value is $2 \%$, and DRC is in 37 th place globally. Mineral rents constituted $13 \%$ out of total GDP and DRC is ranked at number six in 2016. These four variables give the composite score of 93.0 out of 100 in the index for DRC. The top 20 countries in the $2016 \mathrm{MCI}-\mathrm{Wr}$ ranking compared with 2014 are shown in Table 1. All countries with an MCI-Wr index are given in Appendix 1.

There are only three high-income economies (HIE) among the top 50 countries in the $2016 \mathrm{MCI}-\mathrm{Wr}$, but 17 uppermiddle-income economies (UMIEs), 16 lower-middleincome economies (LMIE) and 14 low-income economies (LIEs) (see Table 2). Among the 20 countries with highest MCI-Wr, there are two high-income counties (Australia and Chile) while among the next 30 countries, Canada is the only additional HIE. Clearly, it is a great challenge for emerging economies with a high MCI-Wr index to make sure that they have sound policies, legislation and regulations in place and 


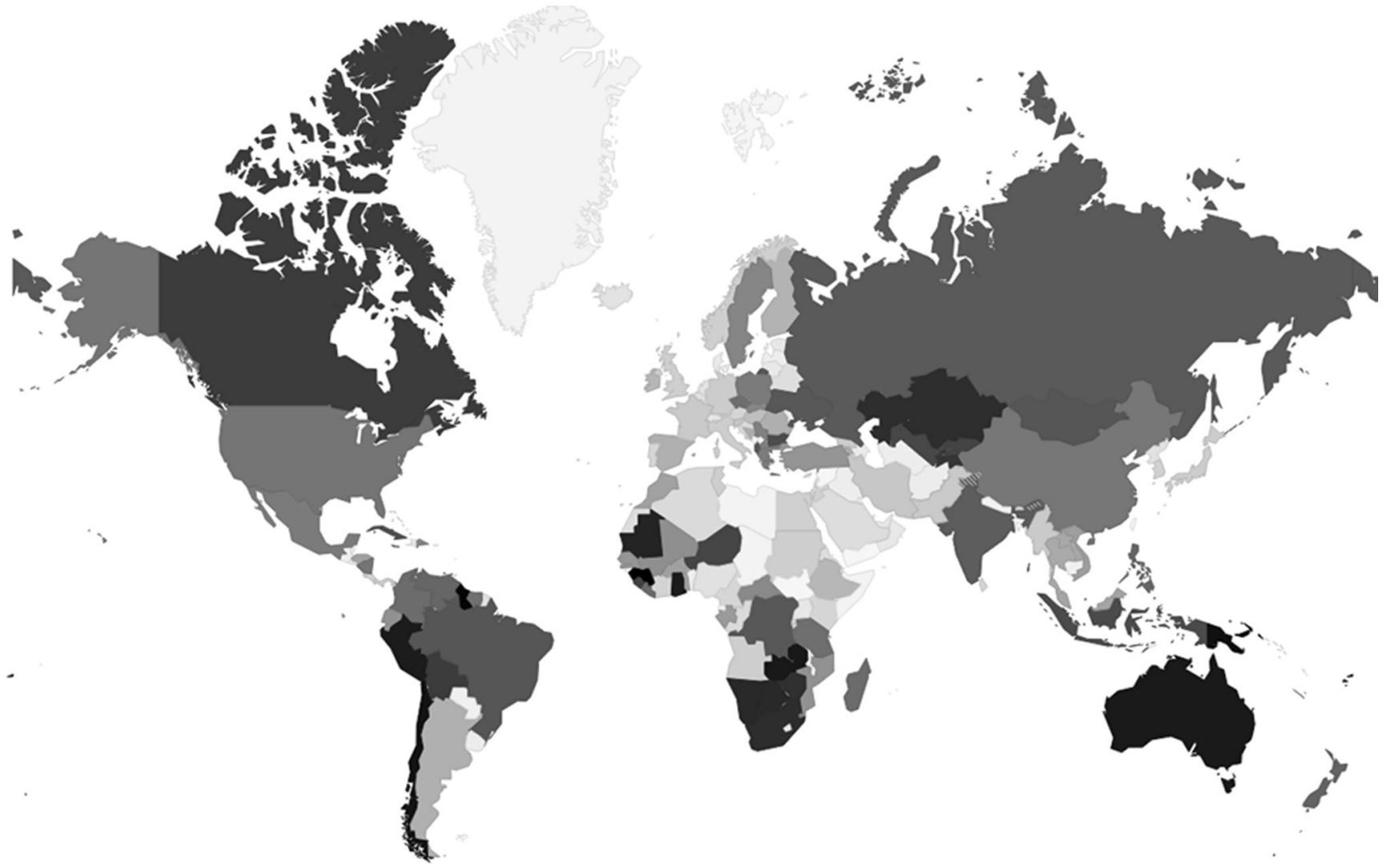

Fig. 2 Mining contribution index (MCI-Wr) score by country 1996

Source: Own calculations.

Table 1 Top 20 revised Mining Contribution Index WIDER (MCI-Wr)

\begin{tabular}{|c|c|c|c|c|c|}
\hline Country & $\begin{array}{l}\text { Rank } \\
1996\end{array}$ & $\begin{array}{l}\text { MCI-Wr score } \\
1996\end{array}$ & $\begin{array}{l}\text { Rank } \\
2016\end{array}$ & $\begin{array}{l}\text { MCI-Wr score } \\
2016\end{array}$ & $\begin{array}{l}\text { Change in } \\
\text { rank }\end{array}$ \\
\hline Congo, Dem. Rep. & 29 & 72.2 & 1 & 93.0 & $\uparrow$ \\
\hline Burkina Faso & 64 & 55.6 & 2 & 92.9 & $\uparrow$ \\
\hline Mali & 57 & 59.4 & 3 & 91.6 & $\uparrow$ \\
\hline $\begin{array}{c}\text { Papua New } \\
\text { Guinea }\end{array}$ & 3 & 89.5 & 4 & 91.1 & $\downarrow$ \\
\hline Eritrea & 119 & 24.4 & 5 & 90.3 & $\uparrow$ \\
\hline Namibia & 11 & 83.5 & 6 & 90.1 & $\uparrow$ \\
\hline Mauritania & 9 & 84.9 & 7 & 89.5 & $\uparrow$ \\
\hline Suriname & 42 & 66.5 & 8 & 89.3 & $\uparrow$ \\
\hline Peru & 8 & 86.7 & 9 & 88.3 & $\downarrow$ \\
\hline Liberia & 37 & 67.6 & 10 & 88.2 & $\uparrow$ \\
\hline Botswana & 10 & 83.8 & 11 & 88.2 & $\downarrow$ \\
\hline Chile & 4 & 88.6 & 12 & 87.8 & $\downarrow$ \\
\hline Zambia & 5 & 87.5 & 13 & 87.3 & $\downarrow$ \\
\hline Guyana & 2 & 90.8 & 14 & 87.2 & $\downarrow$ \\
\hline Sierra Leone & 19 & 77.2 & 15 & 87.1 & $\uparrow$ \\
\hline Mongolia & 27 & 72.8 & 16 & 86.0 & $\uparrow$ \\
\hline Australia & 6 & 87.4 & 17 & 84.6 & $\downarrow$ \\
\hline Guinea & 1 & 91.7 & 18 & 84.3 & $\downarrow$ \\
\hline Tanzania & 41 & 66.9 & 19 & 83.4 & $\uparrow$ \\
\hline Kyrgyz Republic & 20 & 77.0 & 20 & 83.2 & $\leftrightarrow$ \\
\hline
\end{tabular}

Source: Own calculations 
Table 2 MCI-Wr Top 50 by country classification

\begin{tabular}{lll}
\hline $\begin{array}{l}\text { Country } \\
\text { classification }\end{array}$ & 2016 number & 2014 number \\
\hline HIE & 3 & 4 \\
UMIE & 17 & 14 \\
LMIE & 16 & 19 \\
LIE & 14 & 13 \\
Total & 50 & 50 \\
\hline
\end{tabular}

Russia was a high-income country in 2014 but is an upper-middle-income economy in 2016

Source: World Bank

competent staff implement them in order to make sure that benefits continue to flow from the mining sector and that they are used in a sustainable way.

Figure 3 is a four-dimensional chart with the export contribution shown on the $X$-axis and mineral value as percentage of GDP on the $Y$-axis. The size of the circles is proportional to the value of mine production in absolute terms (USD). The fourth dimension is time: the data presented in the printed graph is just for 2016 for obvious reasons. Figure 3 shows the top 30 MCI-Wr countries. Australia has the largest mining industry by value of production as indicated by the size of the circle. The export contribution of mining is highest in Botswana, Sierra Leone, DR Congo and Mongolia at levels of $80-90 \%$ of total exports, followed by, Mali, Burkina Faso and Zambia with export contribution levels at around $70-80 \%$. The figure confirms that the countries with the highest levels of export contribution are mainly low- or lower-middle-income economies. Guyana is the country with the highest contribution of mining as share of GDP at $18 \%$ of the value of all non-fuel minerals at the mine stage. Mongolia and the DR Congo follow next at $12-15 \%$. Eritrea with only one mine (Bisha, gold) of industrial scale in operation in 2014 and two in 2016 (Zara copper/gold was gradually taken into operation in 2015/16) is represented by a small light blue circle. It is the country with the smallest value of its mining production included in the figure.

\section{Indicators in $\mathrm{MCl}-\mathrm{Wr}$}

\section{Value of mine production}

Coal constitutes roughly half of the total value of industrial mine production globally. Iron ore, copper and gold follow next. Nickel and zinc are each roughly an order of magnitude smaller and approximately the same level as the fertilizer minerals phosphate and potash: $2-3 \%$ of the total value of production at the mine stage. A number of metals and industrial minerals follow, which each contributes less than $1 \%$ of total global value of mine production (see Fig. 4). In 2016, the total global value of mine production at the mine stage including coal was around 1000 billion USD. Coal contributed 470 billion USD, and iron ore 125 billion USD. The change over time in the total global value of mineral production follows the general metal/mineral prices developments. For individual countries, however, changes in production volumes, start of entirely new mines, expansion of existing ones or closure of depleted operations are equally or more important. For example, copper production in DRC has increased tenfold over the last 10 years and is now twice as large as during the previous peak in the 1980s.

The value of metal and mineral production at the mine stage is expressed as a percentage of GDP. This figure provides a sense of the scale of value of production relative to the size of the economy. ${ }^{14}$

While there are 30 low- and lower-middle-income economies among the top $50 \mathrm{MCI}-\mathrm{Wr}$ countries, the high-income and upper-middle-income economies are substantially more important in terms of metal and mineral production value, for example China, Australia, USA, Canada, Chile, Russia, South Africa and Brazil (see Fig. 5 and Table 3). It should be noted that the main engine of metal and mineral demand - China — is also by far the most important mining country when coal is included. If coal is not considered, only metals and industrial minerals of Australia and China are roughly of the same size by this measure. The top ten countries in terms of the value of their mine production contribute $75 \%$ of the total value of non-fuel mineral production at the mine stage globally. The absolute levels of production are relatively small for several of the states in the MCI-Wr, such as Guyana, Eritrea and Guinea but for the economy in a broader sense mining is an important contributor to all the states in the top 50 .

Among the 20 countries with the highest production values in Table 3, only Australia, Chile, Peru and the DRC are among the highest-scoring MCI-Wr countries in 2016. Except Australia and Chile, no other country among the highest ranked MCI-Wr countries account for more than $0.7 \%$ of the total value of mine production in 2016. All the countries in the MCI-Wr top 20 together account for $19.1 \%$ of total world production value, but Chile and Australia together, the only high-income countries, stand for $13.3 \%$.

For each of the MCI-Wr top 20 low- and middle-income economies, Fig. 6 shows how metals and minerals contributed to the total value of their mine production in 2016. Gold mining is the major contributor in no less than nine countries in this top 20. In Mali and Suriname, gold is the only metal mined and hence contributes $100 \%$ of the total value, and in Burkina Faso, Guyana, Ghana, Uzbekistan and Tanzania gold mining contributes between 84 and $94 \%$. Copper is the most important commodity in Zambia, DR Congo and Laos. Diamonds are the

\footnotetext{
${ }^{14}$ This figure does not represent the contribution of mining to GDP - on average, perhaps only a third of production value represents value addition to the national economy compare, ICMM 2014.
} 


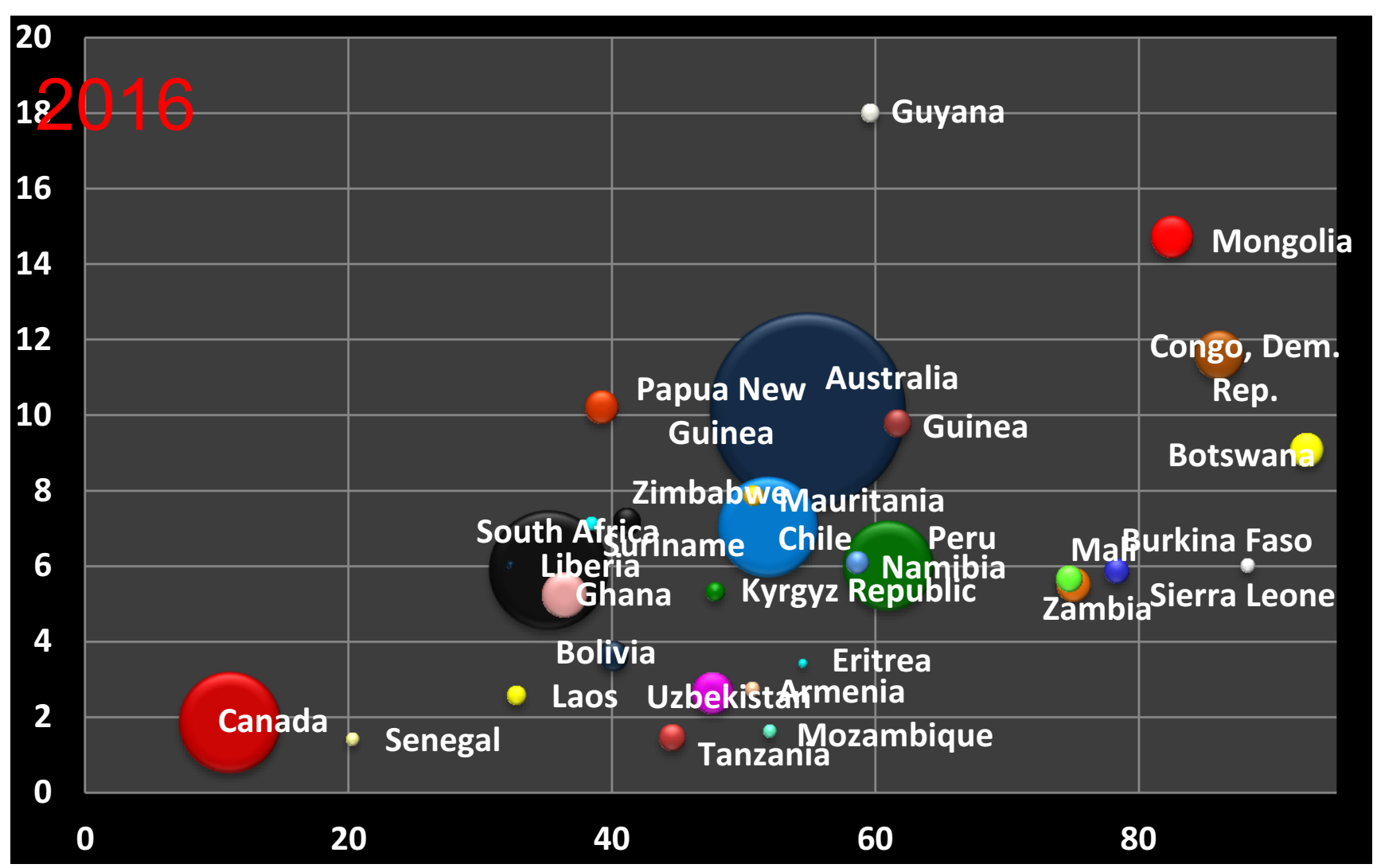

Fig. 32016 MCI-Wr Top 30 countries (circles are proportional to value of total mine production) Source: Own calculations.

main contributor in Namibia and Botswana. Figure 6 also illustrates the vulnerability of many countries to metal price volatility be it gold or copper, iron ore or coal. The situation is slightly different for the diamond-producing countries because the oligopolistic situation in the diamond market probably has a stabilizing effect.

\section{Export of minerals and metals}

International trade in minerals and metals reflects regional and national advantages and specializations along the value chain. (Tercero 2016) The export contribution of metals and minerals provides a measure of the scale of mining in relation to other

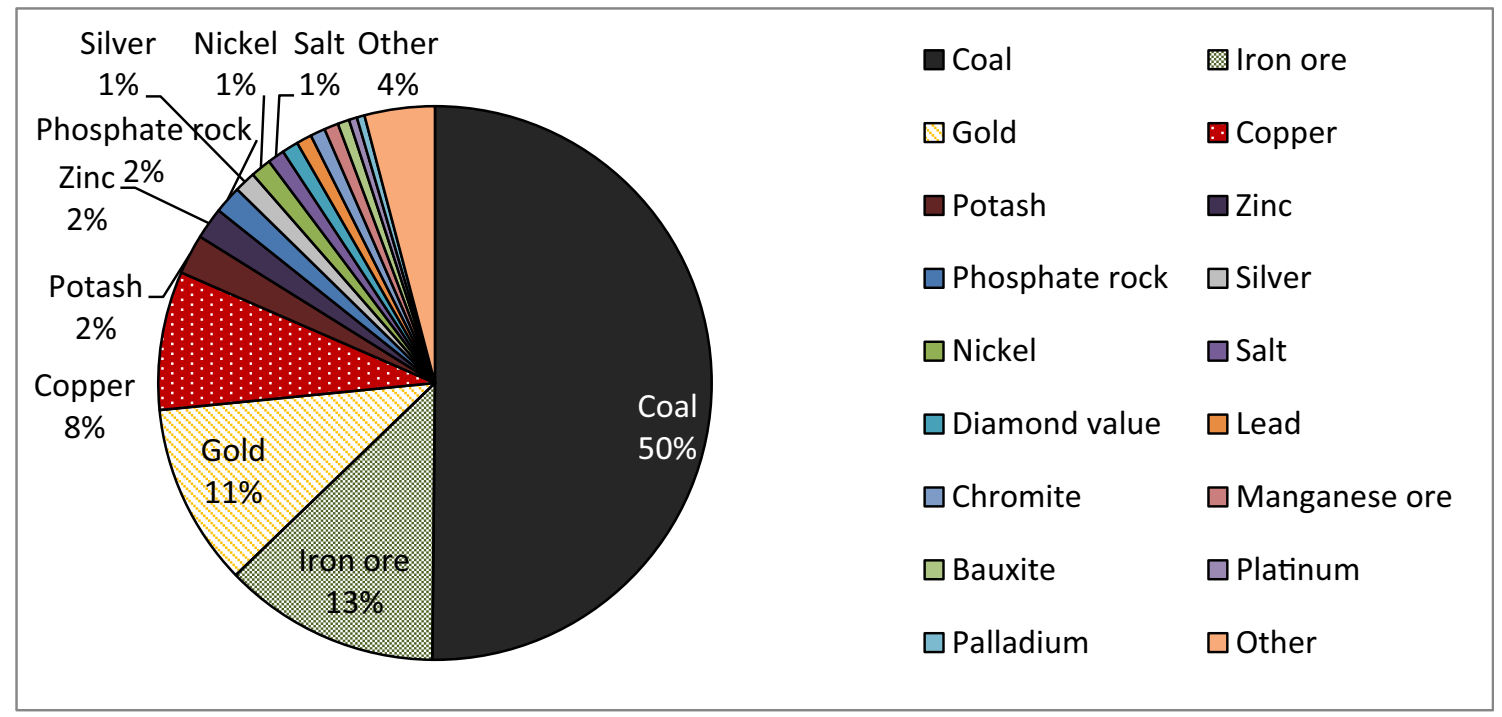

Fig. 4 Total value at the mine stage of metals and minerals 2016 (\%) Source: RMG Consulting based on World Mining Data, British Geological Survey, UNCTAD 2016, and US Geological Survey 


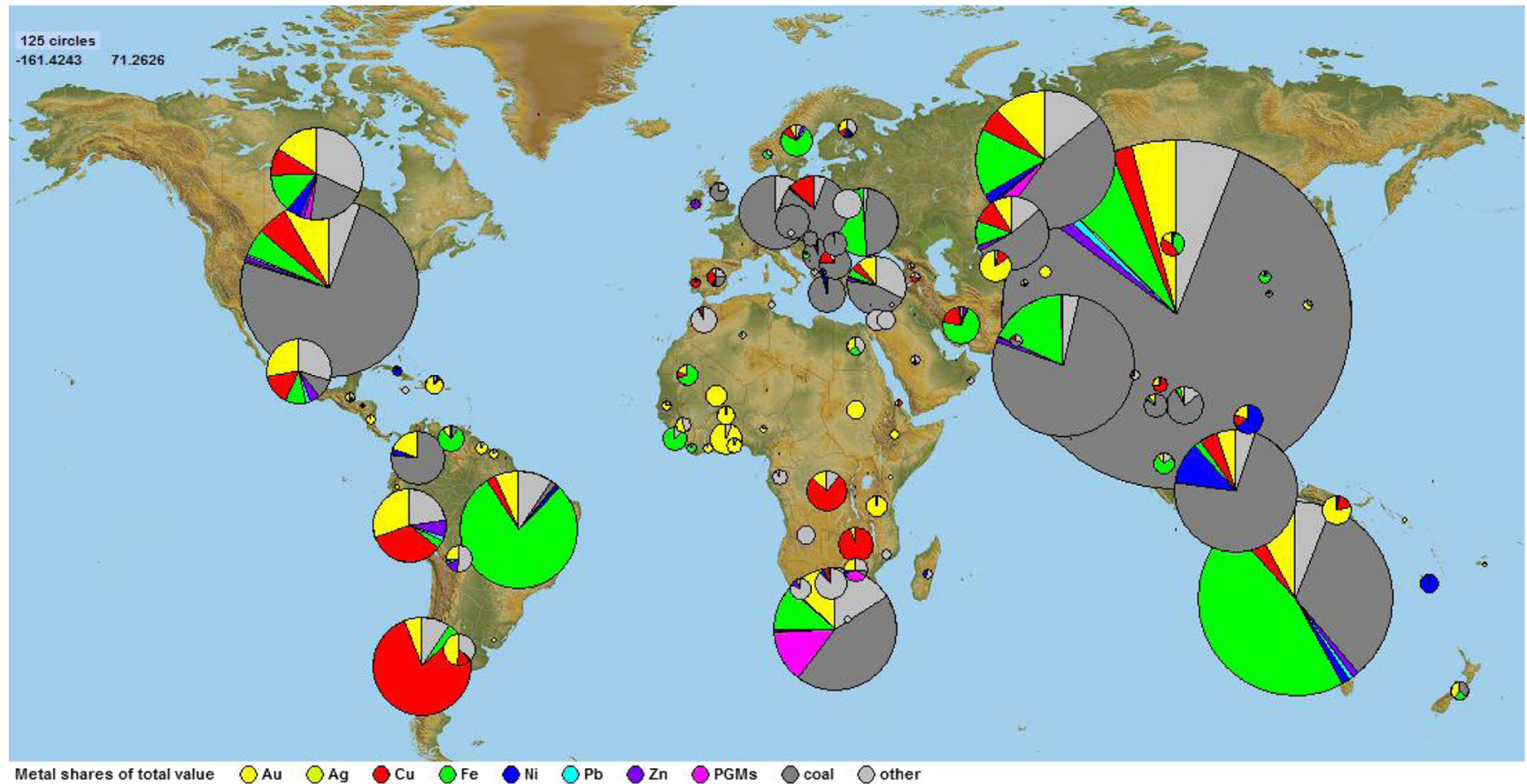

Fig. 5 Value of mine production by country mid-2010s (circles are proportional to value of mine production) Source: Raw Materials Data

Table 3 Value of mine production Top 20 countries

\begin{tabular}{|c|c|c|c|c|c|c|}
\hline Country & $\begin{array}{l}\text { Mine value } 2016 \\
\text { billion USD }\end{array}$ & $\begin{array}{l}2016 \\
(\%)\end{array}$ & $\begin{array}{l}\text { Mine value } 1996 \\
\text { billion USD }\end{array}$ & $\begin{array}{l}1996 \\
(\%)\end{array}$ & $\begin{array}{l}\text { Income } \\
\text { group } 2016\end{array}$ & $\begin{array}{l}\text { Income } \\
\text { group } 1996\end{array}$ \\
\hline China & 304.3 & 29.6 & 69.8 & 22.4 & UM & $\mathrm{L}$ \\
\hline Australia & 108.5 & 10.5 & 24.9 & 8.0 & $\mathrm{H}$ & $\mathrm{H}$ \\
\hline $\begin{array}{l}\text { United } \\
\text { States }\end{array}$ & 72.2 & 7.0 & 53.4 & 17.1 & $\mathrm{H}$ & $\mathrm{H}$ \\
\hline India & 62.2 & 6.0 & 15.3 & 4.9 & LM & $\mathrm{L}$ \\
\hline $\begin{array}{l}\text { Russian } \\
\text { Federati- } \\
\text { on }\end{array}$ & 61.0 & 5.9 & 18.5 & 5.9 & $\mathrm{UM}$ & LM \\
\hline $\begin{array}{l}\text { South } \\
\text { Africa }\end{array}$ & 40.4 & 3.9 & 19.2 & 6.1 & UM & $\mathrm{UM}$ \\
\hline Indonesia & 38.6 & 3.8 & 4.6 & 1.5 & LM & LM \\
\hline Brazil & 36.5 & 3.5 & 7.2 & 2.3 & $\mathrm{UM}$ & UM \\
\hline Canada & 29.2 & 2.8 & 10.8 & 3.5 & $\mathrm{H}$ & $\mathrm{H}$ \\
\hline Chile & 28.6 & 2.8 & 6.8 & 2.2 & $\mathrm{H}$ & UM \\
\hline Peru & 23.1 & 2.2 & 2.8 & 0.9 & UM & $\mathrm{LM}$ \\
\hline Kazakhstan & 17.5 & 1.7 & 4.4 & 1.4 & UM & LM \\
\hline Mexico & 16.4 & 1.6 & 3.0 & 1.0 & UM & UM \\
\hline Germany & 14.2 & 1.4 & 10.2 & 3.3 & $\mathrm{H}$ & $\mathrm{H}$ \\
\hline Poland & 11.2 & 1.1 & 9.2 & 3.0 & $\mathrm{H}$ & UM \\
\hline Turkey & 10.6 & 1.0 & 3.3 & 1.1 & UM & LM \\
\hline Colombia & 8.8 & 0.9 & 1.6 & 0.5 & UM & $\mathrm{LM}$ \\
\hline $\begin{array}{c}\text { Congo, } \\
\text { Dem. } \\
\text { Rep. }\end{array}$ & 6.8 & 0.7 & 2.3 & 0.7 & $\mathrm{~L}$ & $\mathrm{~L}$ \\
\hline Ukraine & 6.6 & 0.6 & 4.6 & 1.5 & LM & LM \\
\hline Ghana & 5.9 & 0.6 & 0.7 & 0.2 & LM & $\mathrm{L}$ \\
\hline Total top 20 & 903 & 87.7 & 273 & 87.4 & - & - \\
\hline Total & 1029 & 100 & 311.9 & 100 & - & - \\
\hline
\end{tabular}

Source: Raw Materials Data and RMG Consulting 


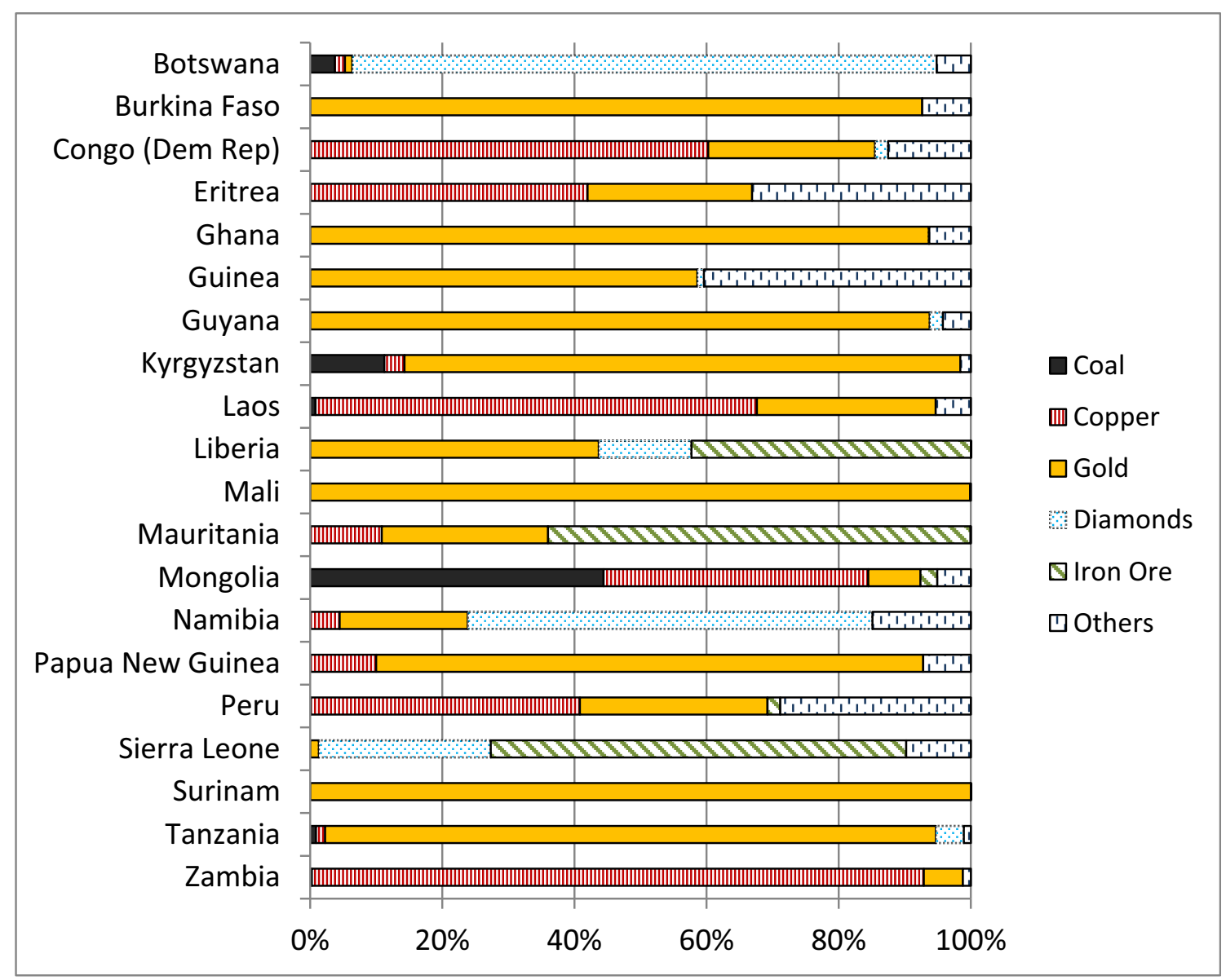

Fig. 6 Contribution by commodity to MCI-Wr for Top 20 low- and middle income economies (\%) Source: RMG Consulting

export activities, in particular for small low- and middleincome countries.

Non-fuel minerals are major contributors to many nations' exports. Among the top 50 countries with the highest non-fuel mineral exports relative to total exports in 2016, there are 21 with a total mineral export of more than $50 \%$ of the total. Among the top 50 countries, ranked by export contribution, 18 are low-income economies and 14 are lower-middle-income economies. Only 9 countries are high-income economies (see Tables 4 and 5). The export contribution to the MCI-Wr score in low- and middle-income economies is the single most important factor explaining their high ranks. Botswana has the highest share of minerals in its exports of $93 \%$ of total exports. Sierra Leone, DR Congo and Mongolia are all countries where nonfuel mineral exports account for more than $80 \%$ of total exports.

\section{Exploration}

Global exploration is more volatile than mine production and varies, with a time lag, with metal prices. ${ }^{15}$ In 1996, global

$\overline{15}$ Overview of trends in Canadian mineral exploration 2000, Canadian Intergovernmental Working Group on the Mineral Industry, pp. 20-21, Natural Resources Canada 2001. exploration expenditure was just below 5 billion USD. Activities dwindled in the early 2000s and reached a trough in 2002 at around 2 billion USD. At the height of the 'super cycle', exploration peaked above 21 billion USD only to be reduced to around just a third of that amount in 2016. Since then, exploration has been expanding slowly again. These figures are published by SNL Metals \& Mining and include most metal exploration except iron ore and further not coal. As mentioned earlier, there are other shortcomings in these figures but none of them are considered serious enough not to include exploration in the MCI-Wr index. Exploration expenditure figures for individual countries vary in a similar way as global figures do and sometimes are even more volatile. Exploration

Table 4 Top 50 export contribution by country classification

\begin{tabular}{lll}
\hline Country classification & 2014 number & 2016 number \\
\hline HIE & 9 & 9 \\
UMIE & 9 & 9 \\
LMIE & 15 & 14 \\
LIE & 17 & 18 \\
Total & 50 & 50 \\
\hline
\end{tabular}

Sources: UNCTAD, World Bank 
Table 5 Top 20 mineral export contributors 2016

\begin{tabular}{|c|c|c|c|c|}
\hline Country & $\begin{array}{l}\text { Country } \\
\text { classification }\end{array}$ & $\begin{array}{l}\text { Export } \\
\text { contribution } 2014\end{array}$ & $\begin{array}{l}\text { Export } \\
\text { contribution } 2016\end{array}$ & $\begin{array}{l}\text { Change export contribution } \\
16 / 14(\%)\end{array}$ \\
\hline Botswana & UM & 91.3 & 92.7 & 1.5 \\
\hline Sierra Leone & $\mathrm{L}$ & 93.6 & 88.2 & -5.7 \\
\hline $\begin{array}{l}\text { Congo, Dem. } \\
\text { Rep. }\end{array}$ & $\mathrm{L}$ & 80.9 & 86.0 & 6.4 \\
\hline Mongolia & LM & 80.4 & 82.5 & 2.6 \\
\hline Burkina Faso & $\mathrm{L}$ & 49.6 & 78.3 & 57.7 \\
\hline Zambia & LM & 75.1 & 75.0 & -0.1 \\
\hline Mali & $\mathrm{L}$ & 65.7 & 74.7 & 13.6 \\
\hline Nauru & $\mathrm{UM}$ & 83.3 & 72.1 & -13.4 \\
\hline $\begin{array}{l}\text { French } \\
\quad \text { Polynesia }\end{array}$ & $\mathrm{H}$ & 68.2 & 64.9 & -4.8 \\
\hline Guinea & $\mathrm{L}$ & 52.1 & 61.6 & 18.4 \\
\hline Peru & $\mathrm{UM}$ & 53.8 & 61.0 & 13.4 \\
\hline Guyana & UM & 61.2 & 59.6 & -2.6 \\
\hline Namibia & UM & 50.3 & 58.6 & 16.6 \\
\hline Australia & $\mathrm{H}$ & 56.7 & 54.9 & -3.3 \\
\hline Tajikistan & LM & 59.1 & 54.7 & -7.4 \\
\hline Eritrea & $\mathrm{L}$ & 38.6 & 54.5 & 41.0 \\
\hline Korea, DPR. & $\mathrm{L}$ & 49.1 & 52.7 & 7.5 \\
\hline Mozambique & $\mathrm{L}$ & 51.1 & 51.9 & 1.6 \\
\hline Chile & $\mathrm{H}$ & 57.0 & 51.9 & -9.1 \\
\hline Mauritania & LM & 58.1 & 50.7 & -12.6 \\
\hline
\end{tabular}

Sources: UNCTAD, World Bank

figures give a dynamic aspect of mining activities in the sense that high exploration expenditures and activities could, if successful, lay the foundation for increased mine production 1015 years later. Over the period since 1996, the ratio of global exploration expenditure to the value of total global mine production has varied between $1.7 \%$ in 1996 and $0.7 \%$ in 2016 with two peaks above $1 \%$ in between. For some of the countries with high MCI-Wr scores in 2016, this ratio has been much higher in periods, for example Burkina Faso had ratios around 100\% during a couple of years between 1996 and 2007. These exploration efforts have made it possible to start and expand mine production in the country in later years and the concomitant increase in the MCI-Wr index. Mali, Eritrea, Papua New Guinea, Liberia and Tanzania are other countries where exploration during periods since 1996 has been on much higher levels than the global average, albeit not reaching the figures of Burkina Faso. Some of the other countries in the MCI-Wr top 30, such as Mauritania, Peru, Botswana, Chile and Australia have had lower exploration ratios possibly indicating lower probability of quick future expansions of their mine production. In 2016, the highest ratio is calculated for Senegal 8.5\%, Eritrea 4.69, Burkina Faso 4.04, Mali 3.49 and Canada $3.32 \%$ respectively. At the low end are Zimbabwe and Uzbekistan both $0.43 \%$, Mongolia $0.48 \%$, Guinea 0.56 , Guyana $0.81 \%$ and Australia $0.83 \%$. The differences in actual spending are of course big, most funds are spent in Canada at
0.99 billion USD, and Australia is number two at 0.90 billion. Exploration expenditure is down to 151 million USD for DRC, 73 Burkina Faso, Mali 70 and Papua New Guinea 101, all million USD. For the countries with lower MCI-Wr scores, the absolute amounts spent on exploration in 2016 were a couple of tens of million USD (see Table 6).

Exploration expenditure depends on a range of factors including geological prospectivity, the potential to make a discovery and later the likelihood to take this deposit into an operating mine. Other drivers are mining and environmental legislation, security of tenure, tax system, availability of infra structure and competent and trained staff. ${ }^{16}$ All these factors are directly or indirectly influenced by national and local political decisions. Even geological potential can be influenced by geological mapping and research into processes of ore formation etc.

\section{Mineral rents}

Mineral rents vary considerably over time and between countries. Among the countries with the highest MCIWr score in 2016, Suriname, Mauritania, and Mongolia had mineral rent figures over $20 \%$ of GDP $(24.0,22.3$

\footnotetext{
${ }^{16}$ James Otto, The competitive position of countries seeking exploration and development investment, Journal of the Society of Economic Geologist, Special Publication 12, pp. 1-17, 2006.
} 
Table 6 Top 20 MCI-Wr countries and exploration

\begin{tabular}{lll}
\hline Country & MCI-Wr rank 2016 & $\begin{array}{l}\text { Exploration } \\
\text { rank 2016 }\end{array}$ \\
\hline Congo, Dem. Rep. & 1 & 10 \\
Burkina Faso & 2 & 13 \\
Mali & 3 & 18 \\
Papua New Guinea & 4 & 20 \\
Eritrea & 5 & 75 \\
Namibia & 6 & 38 \\
Mauritania & 7 & 43 \\
Suriname & 8 & 41 \\
Peru & 9 & 5 \\
Liberia & 10 & 70 \\
Botswana & 11 & 32 \\
Chile & 12 & 4 \\
Zambia & 13 & 29 \\
Guyana & 14 & 51 \\
Sierra Leone & 15 & 83 \\
Mongolia & 16 & 45 \\
Australia & 17 & 2 \\
Guinea & 18 & 33 \\
Tanzania & 19 & 15 \\
Kyrgyz Republic & 20 & 25 \\
\hline
\end{tabular}

Source: SNL Metals \& Mining World exploration trends, various years

and 21.5 respectively). A second group of countries including Liberia, DRC, Guyana and PNG has mineral rents between 10 and $20 \%(17.6,13.2,11.8$ and 11.3 respectively). For all these countries except Papua New Guinea, the contribution to GDP by mineral rents increased with 10 times (DRC) and two times for Guyana and Liberia. Mineral rents as a percentage of GDP decreased from $12.4-11.3 \%$ for PNG. Given the uncertainties discussed in the Methodology section above, it seems as if a careful recalculation of the mineral rents would be useful in order to determine more precisely their contribution to national economies or perhaps the replacement of this indicator by using value added in the sector. Among countries with low mineral rents (less than 5\%) are Australia (5.0\%), South Africa (4.6), Tanzania (3.0), Bolivia (2.8), Mozambique (2.3) and Senegal (1.8\%). Also among these countries, there had been an increase since 1996. Australia and South Africa would have considerably higher mineral rents if also coal would have been included as both these counties are important coal producers.

\section{Other factors}

In addition to the four indicators studied, there are other remaining ones, which ideally should be measured but are not because there is a lack of comparable data. Two of the most import ones not included in the calculations are government revenues and employment. In spite of this, it is important to present at least a brief discussion, based on some data not coherent and not covering all countries for all years but still giving some indications to the importance of these indicators. ${ }^{17}$ Additional indicators, which could also be important to include are foreign direct and total investments into mining, and mineral wealth created. There is however not sufficient annual data over the entire period to make any further calculations for investments meaningful. Mineral wealth developments are treated in increasing detail by the World Bank in the study The Changing Wealth of Nations 2108. Non-fuel mineral resources grew very rapidly between 1995 and 2014, more than 10 times from 997 to 10.154 billion USD. This is by far the largest increase of all asset types measured in this study. It would be interesting to include also wealth developments into a future mining contribution index.

\section{Government revenues $^{18}$}

The capturing by government of some part of total resource revenues as government revenues (mainly taxes and royalties) is crucial to generate development for many reasons, not least that the mineral resources are considered non-renewable. From Fig. 7, (which uses those IMF data that are available), it is clear that there is lagged relationship between metal prices and government revenues. Metal prices started upwards in 2002/2003 and government revenues increased a year or two later in most counties that are shown in the graphic. Among the countries in this limited sample, government revenues grew until 2011/2012 and then fell back sharply at least for some countries while continuing upwards for others (e.g. Ghana). This is probably explained by the fact that Ghana is an important gold producer and the gold price has not fallen as quickly as some of the base metals. The IMF data are not complete for the full period until 2014, and for Zambia and Guinea, there are unfortunately no recent figures. The quick growth of mining in Mongolia has resulted in an equally rapid increase of government revenues but the volatility is also high making it difficult for mineral rich countries such as Mongolia to plan for their futures.

\footnotetext{
${ }^{17}$ This approach parallels that of the ICMM in its most recent report on the topic (ICMM-2016).

${ }^{18}$ This section and the following on employment are cited directly (with minor additions) out of the UNU Wider Working Paper 2017/148. In this working paper there is also a more detailed discussion of employment in some mining countries.
} 
Fig. 7 Government revenues from mining as a share of GDP (\%)Source: IMF Resource Revenue Data, 2016. Note: For details on the price index please see note of Fig. 14

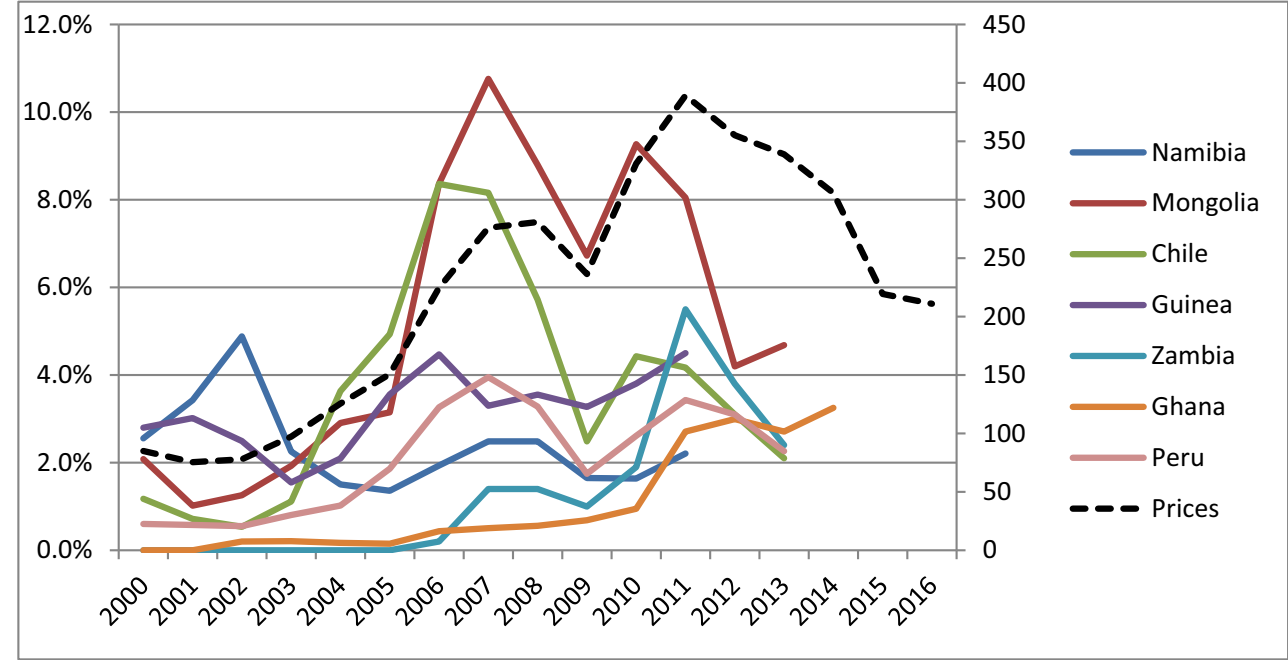

\section{Employment}

It has not been possible to include employment in the mineral sector as one of the contributing factors to the MCI-Wr mining contribution index because of lack of data.

Direct employment in the mining sector most often varies between 1 and $3 \%$, but there are examples of much higher levels. ${ }^{19}$ This is invariably the case, if informal/artisanal sector employment is also included. Employment is an important stabilising factor in the contribution of mining in many mineral-rich countries. Employment has also been generally rising in the past 10 years, and has not declined as much recently as the value of mine production, exports and other factors directly related to commodity prices. Employment is further somewhat less volatile than the other factors under study, and there was for example only a marginal dip during the global financial crisis in 2008-2009.

The employment effects of mining, directly and indirectly, is a key area for further research.

\section{Impact of the end of the 'super cycle'}

The global mining industry experienced a period of unprecedented change during the first 15 years of the new millennium. Metal and mineral prices had been on low levels for an extended period in the 1990s and into the new millennium. A period with low profitability and limited investments very quickly turned into a situation with record high metal prices, improved profitability and a plethora of new investment projects. It was mainly the strong demand for metals and minerals in China which drove these developments. Metal prices have dropped since the peak in $2011 / 2012$, but not to pre-boom

$\overline{{ }^{19} \mathrm{ICMM} 2014 .}$ levels, and in 2017, there was a turn-around in the market, which seems to be lasting. Gold stands out in that its price did not fall as precipitously as several other metals.

Gold is the single most important metal for the highest MCI-Wr ranking LIEs and MIEs. Forty-one percent of the total value of their mine output comes from gold. Gold is the main contributor in nine out of these 20 countries. Table 7 lists those 20 LIE and MIEs in the top 50 MCI-Wr counties where gold was the single largest contributor to the value of mine production in 2016. In all 20 countries, gold mining contributed more than $50 \%$ of the total value of all metal and mineral production. In Surinam, Mali and the Sudan, gold contributed $100 \%$ of total value. Among all the LIEs and MIEs together there is a total of 24 nations where gold mining is the main contributor. When also small-scale/artisanal gold mining is considered (such production is often fully accounted for in the national statistics used), the importance of gold production and the significance of the relative stability of the gold price are even greater. This is particularly important for a number of LIEs like Sudan, Burundi and Cameroon where small-scale/ artisanal gold production is considerable.

Two examples are demonstrated in Figs. 8 and 9. The figures show the total value of metal and mineral production relative to GDP on the vertical axis and the metal and mineral export as a percentage of total exports on the horizontal for every year since 1996. The line joins these annual readings together in chronological order. Burkina Faso had only limited mining in early 2000s and the production value as percentage of GDP was close to zero and exports were accordingly very low. By 2016, the production value as a percentage of GDP was around $6 \%$ and exports as percentage of total exports were growing continuously. In 2016 the contribution to exports by gold had increased to almost $80 \%$. Gold output in Burkina Faso was expanded less rapidly from 2012 onwards and remained around $35 \mathrm{t}$, while the average annual gold price 
Table 7 Share of total value of mineral production for gold

\begin{tabular}{llll}
\hline Country & $\begin{array}{l}\text { Gold } \\
\text { production } \\
\text { 2016 (tonnes) }\end{array}$ & $\begin{array}{l}\text { Gold } \\
\text { contribution }\end{array}$ & $\begin{array}{l}\text { MCI-Wr } \\
\text { rank } \\
2016\end{array}$ \\
\hline Suriname & 13 & 100 & 8 \\
Mali & 47 & 100 & 3 \\
Sudan & 93 & 100 & 41 \\
Cote d'Ivoire & 24 & 95 & 33 \\
Guyana & 22 & 94 & 14 \\
Ghana & 129 & 94 & 21 \\
Burkina Faso & 39 & 93 & 2 \\
Ecuador & 7 & 93 & 66 \\
Tanzania & 44 & 92 & 19 \\
Togo & 14 & 90 & 46 \\
Azerbaijan & 2 & 86 & 79 \\
Ethiopia & 7 & 86 & 112 \\
Kyrgyz Republic & 21 & 84 & 20 \\
Uzbekistan & 100 & 84 & 28 \\
Papua New Guinea & 62 & 83 & 4 \\
Honduras & 3 & 73 & 54 \\
Niger & 1 & 69 & 36 \\
Dominican & 38 & 67 & 43 \\
Republic & & 62 & 50 \\
Argentina & 56 & 59 & 18 \\
Guinea & 30 & & \\
\hline
\end{tabular}

Source:RMG Consulting

had decreased $12 \%$ between 2012 and 2016. The value of mine production as a percentage of GDP remained at the same levels from 2012 and onwards. This example of Burkina Faso confirms that the impact of the end of the 'super cycle' has been smaller for countries where gold mining is important than for countries mining other metals and minerals such as copper in Mongolia.

Mongolia is ranked as number 16 on the MCI-Wr 2016. It is dependent on copper and coal for about $70 \%$ of its total mineral output. Copper production doubled between 2011 and 2016 but in spite of that mine value as percentage of GDP decreased from $25 \%$ in 2011 to about $17 \%$ in 2016, there is a decrease of $30 \%$ (see Fig. 9). The copper price fell by almost $50 \%$ in the same period explaining a part of the decline in mining's contribution. Other sectors of the economy having grown at a higher rate than the economy in general have probably offset the negative effect of declining copper prices Mongolia is however still heavily dependent on mineral exports, around $80-85 \%$ in the years $2006-2016$. The contribution of mining to the economy of Mongolia will most probably remain on a high level.

Countries have been hit by the end of the 'super cycle' in different ways depending on many factors such as the composition and size of their mineral production. Gold mining countries are experiencing a slower but still continuing growth. The level of exports and mining's share of GDP reached a maximum at the peak of the 'super cycle' in 2011. At that time, GDP contribution reached as high as $25 \%$ for some countries and mining exports went over $85 \%$. These figures have declined for some counties but the situation for most countries is still a significantly larger contribution of mining in 2016 than in 1996. For some countries, production value as percentage

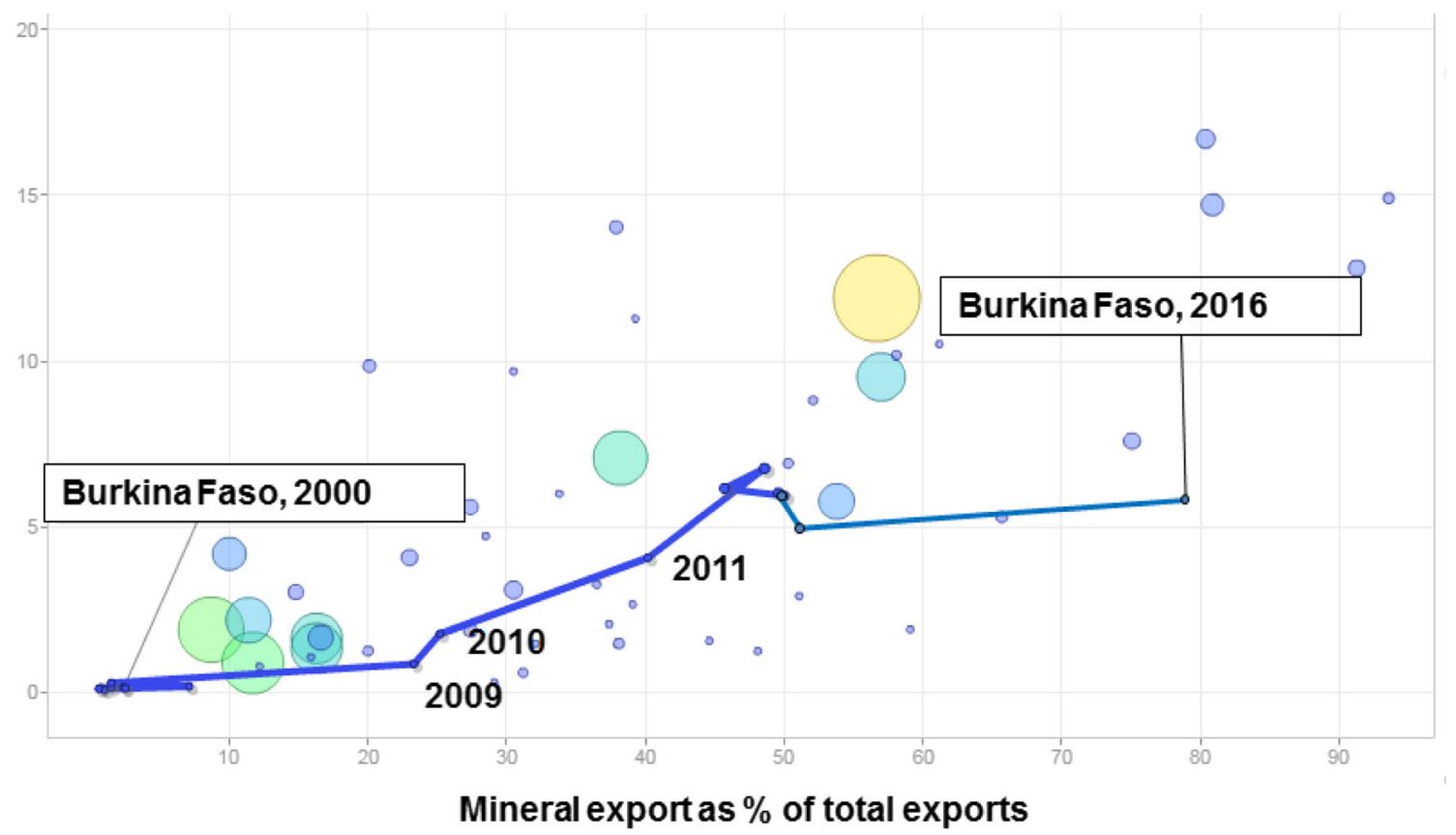

Fig. 8 Burkina Faso, development in export and production values 2000-2016 (circles and circle colours are proportional to value of mine production). Note: Other circles indicate other countries and their position in 2014. Source: Own calculations 


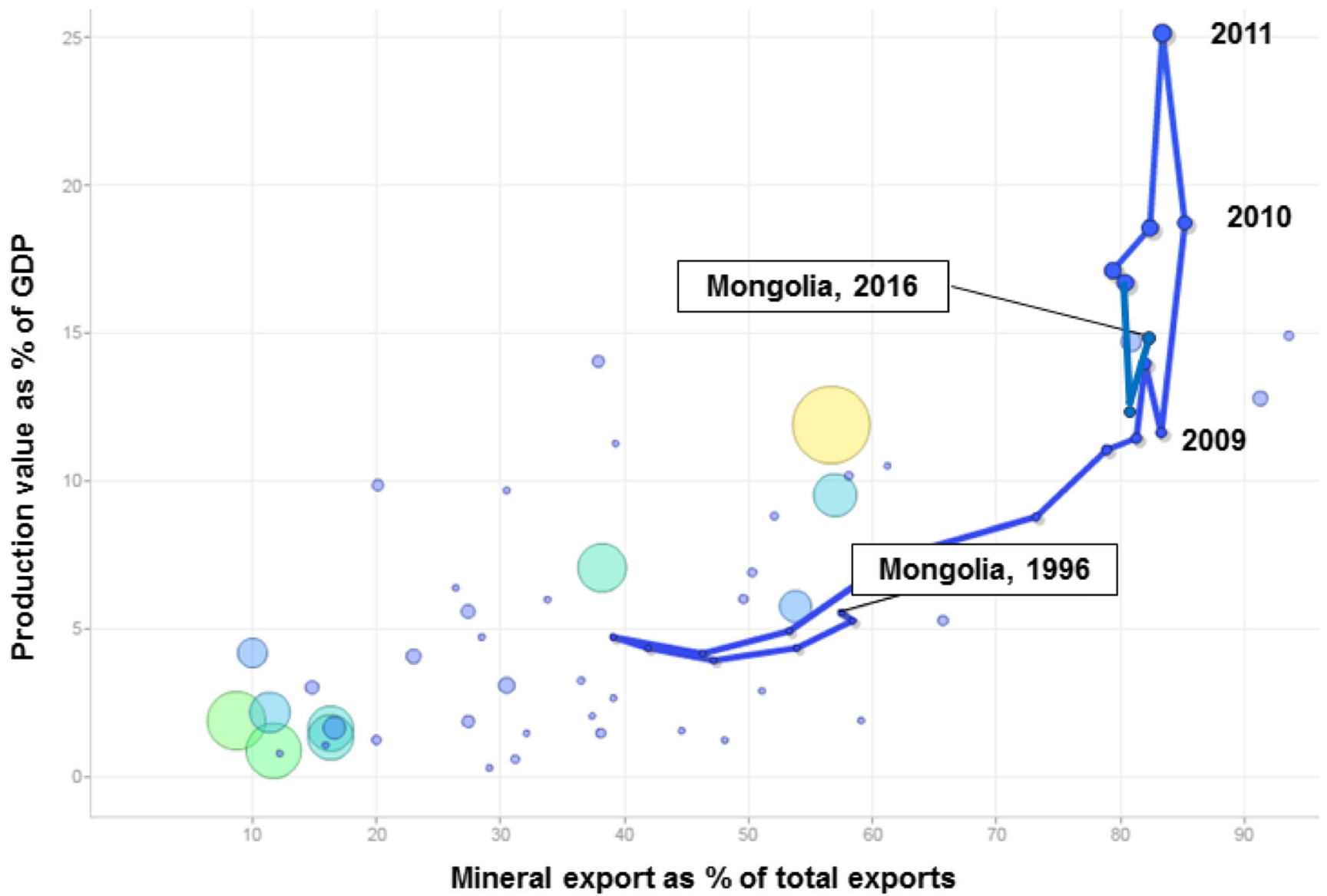

Fig. 9 Mongolia, development in export and production values 2000-2016 (circles and circle colours are proportional to value of mine production). Note: Other circles are other countries and their position in 2014. Source: Own calculations

of GDP and mineral exports is even higher in 2016 because of a strong growth in production offsetting the decline in prices. This is the case for example for the DRC, Sierra Leone and Eritrea. Some of the countries with a higher share of mineral exports in 2016 compared with 2011 are Burkina Faso, Mali, Guyana, Ghana, Namibia, Mauritania, Guinea and Botswana.

\section{Changes in the MCI-Wr between 1996 and 2016}

The value of mineral production at the mine stage was 300 billion USD (in nominal terms) in 1996, equivalent to $0.6 \%$ of total world GDP PPP (World Bank 2016). In 2011, the value of metal and mineral production peaked at 1800 billion USD ( $1.9 \%$ of global GDP). It has since fallen to 1200 billion USD (2016), which is $1.2 \%$ of world total GDP (Fig. 14). The extraordinarily long boom in metal and mineral markets and prices beginning in 2003 made mining a more important part of GDP in almost all mining countries. Mining's share of global GDP doubled in 4 years, and was three times higher in 2011 than it was in 1996. In 2016, there was a trough at only $50 \%$ of the 2011 level, but still $40 \%$ higher than in 1996. This rapid growth and later equally quick decline in value of metal and mineral production naturally had strong effects on MCIWr. The 20 countries with the highest MCI-Wr score in 2016 are shown in Table 8. Of these, ten economies have climbed up one level between 1996 and 2016 in the World Bank income group classification (low (L), lower-middle (LM), upper-middle (UM) and high-income (H) countries). Mauritania, Zambia, Mongolia and Kyrgyzstan were classified as low-income countries in 1996 and in 2016 are classified as lower-middle-income countries. Namibia, Suriname, Peru and Botswana were classified as lower-middle-income countries in 1996 and upper-middle-income countries in 2016. Chile moved from the upper-middle level to become a highincome country in the period. Certainly, there are a host of factors influencing these gradual economic developments, but the contribution of mining is most probably one of the more important ones.

The contribution of mining to national economies in 1996 compared with the situation in 2016 is illustrated in the two 
maps in Figs. 1 and 2. The contribution of mining (the darker coloured countries) has increased for several countries in Latin America and Africa, both West Africa and South and Central Africa. The importance of mining for some countries in Europe, North America and China has decreased in the same period.

Of the 20 countries with the highest MCI-Wr score in 1996, 11 have moved up one or more levels in the World Bank country classification. In addition to the countries mentioned above, Kazakhstan and Russia have moved from the lowermiddle to the upper-middle group. Another seven countries fell out of the group of 20 countries with the highest MCI-Wr score from 1996 to 2016: Canada (HI), South Africa and Brazil (UM), Ghana, Bolivia and Indonesia (LM) and Zimbabwe (L). They were replaced in the top 20 group with the highest MCI-Wr score in 2016 by two LM countries (Mongolia and Kyrgyz Republic) together with seven lowincome countries (DRC, Burkina Faso, Mali, Eritrea, Liberia, Sierra Leone and Tanzania). Most of these newcomers showed a quick increase in MCI-Wr score, while for Sierra Leone, Mongolia and Tanzania, it grew at a slower pace.

We cannot determine if the declining MCI-Wr score means that the economies of these countries have diversified or simply that the mining sector has contracted. It also remains to be seen if the newcomers in the top 20 group of countries in 2016 such DRC, Burkina Faso, Mali, Eritrea and Liberia will benefit from their quickly developing mining sector and consequently MCI-Wr score and move up in the World Bank country classification as many in the 1996 top 20 group did during the past 20 years.

Certain countries have climbed quickly up the rankings: West African countries including Burkina Faso, Mali, Liberia and Sierra Leone have for example moved to the top of the MCI-Wr rankings (see Table 8). Most countries, which show the largest increase in MCI-Wr, had no or only limited industrial mining in 1996 but investments were made during the first decade of the twenty-first century. The exploration expenditures in the early part of the period under study were also high as discussed above. African mining countries in particular have increased their MCI-Wr score. Among the 20 countries for which the MCI-Wr score has increased most between 1996 and 2016, no less than 14 are in Africa (see Table 9).

Mining's contribution to economic activity in the lowand middle-income countries clearly increased between 1996 and 2016. The increase is higher in LIE than in MIE. Mining's share of GDP increased with $43 \%$ during these years for these two categories of country. The share was $1.2 \%$ in 2016 , compared with $0.8 \%$ in 1996 . The

Table 8 Change in country classification 1996-2016

\begin{tabular}{lllll}
\hline Country & 1996 & 2014 & 2016 & $2016 /$ \\
& & & & 1996 \\
& & & & $\uparrow \downarrow$ \\
\hline Congo, Dem. Rep. & $\mathrm{L}$ & $\mathrm{L}$ & $\mathrm{L}$ & $\leftrightarrow$ \\
Burkina Faso & $\mathrm{L}$ & $\mathrm{L}$ & $\mathrm{L}$ & $\leftrightarrow$ \\
Mali & $\mathrm{L}$ & $\mathrm{L}$ & $\mathrm{L}$ & $\leftrightarrow$ \\
Papua New Guinea & $\mathrm{LM}$ & $\mathrm{LM}$ & $\mathrm{LM}$ & $\leftrightarrow$ \\
Eritrea & $\mathrm{L}$ & $\mathrm{L}$ & $\mathrm{L}$ & $\leftrightarrow$ \\
Namibia & $\mathrm{LM}$ & $\mathrm{UM}$ & $\mathrm{UM}$ & $\uparrow$ \\
Mauritania & $\mathrm{L}$ & $\mathrm{LM}$ & $\mathrm{LM}$ & $\uparrow$ \\
Suriname & $\mathrm{LM}$ & $\mathrm{UM}$ & $\mathrm{UM}$ & $\uparrow$ \\
Peru & $\mathrm{LM}$ & $\mathrm{UM}$ & $\mathrm{UM}$ & $\uparrow$ \\
Liberia & $\mathrm{L}$ & $\mathrm{L}$ & $\mathrm{L}$ & $\leftrightarrow$ \\
Botswana & $\mathrm{LM}$ & $\mathrm{UM}$ & $\mathrm{UM}$ & $\uparrow$ \\
Chile & $\mathrm{UM}$ & $\mathrm{H}$ & $\mathrm{H}$ & $\uparrow$ \\
Zambia & $\mathrm{L}$ & $\mathrm{LM}$ & $\mathrm{LM}$ & $\uparrow$ \\
Guyana & $\mathrm{L}$ & $\mathrm{LM}$ & $\mathrm{UM}$ & $\uparrow$ \\
Sierra Leone & $\mathrm{L}$ & $\mathrm{L}$ & $\mathrm{L}$ & $\leftrightarrow$ \\
Mongolia & $\mathrm{L}$ & $\mathrm{UM}$ & $\mathrm{LM}$ & $\uparrow$ \\
Australia & $\mathrm{H}$ & $\mathrm{H}$ & $\mathrm{H}$ & $\leftrightarrow$ \\
Guinea & $\mathrm{L}$ & $\mathrm{L}$ & $\mathrm{L}$ & $\leftrightarrow$ \\
Tanzania & $\mathrm{L}$ & $\mathrm{L}$ & $\mathrm{L}$ & $\leftrightarrow$ \\
Kyrgyz Republic & $\mathrm{L}$ & $\mathrm{LM}$ & $\mathrm{LM}$ & $\uparrow$ \\
\hline So & & & & $\leftrightarrow$ \\
\hline
\end{tabular}

Source: World Bank Data

Table 9 Change in MCI-Wr score 1996-2016

\begin{tabular}{ll}
\hline Country & Change in MCI-Wr score \\
& $2016 / 1996(\%)$ \\
\hline Lesotho & 398 \\
Eritrea & 269 \\
Solomon Islands & 265 \\
Cote d'Ivoire & 105 \\
Burkina Faso & 67 \\
Sudan & 64 \\
Mali & 54 \\
Armenia & 52 \\
Lao PDR & 51 \\
Senegal & 40 \\
Suriname & 34 \\
Mozambique & 33 \\
Liberia & 30 \\
Argentina & 29 \\
Congo, Dem. Rep. & 29 \\
Tanzania & 25 \\
Togo & 23 \\
Gabon & 20 \\
Mongolia & 18 \\
Sierra Leone & 13 \\
\hline
\end{tabular}

Source: Own calculations 


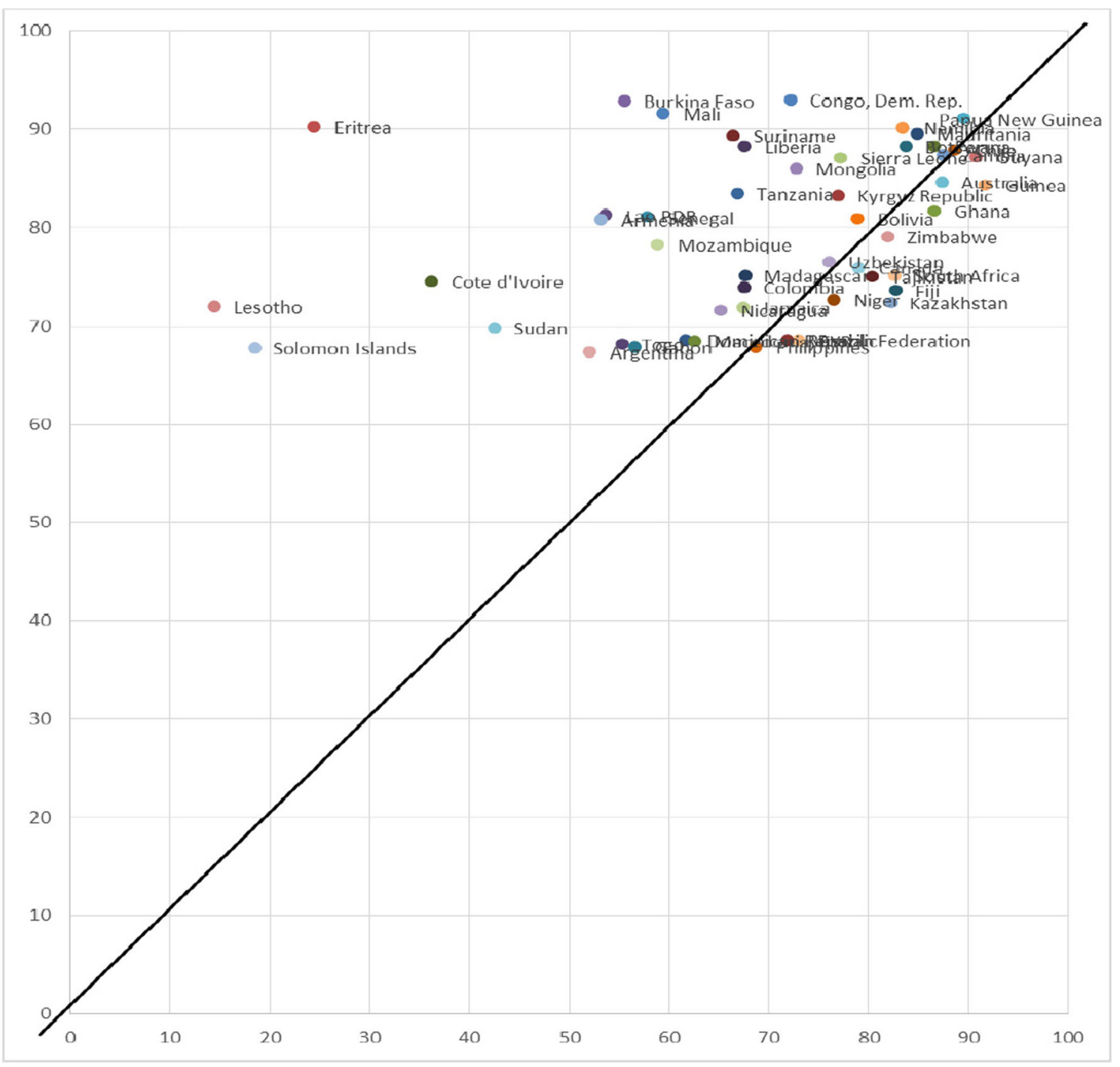

Fig. 10 MCI-Wr for Top 50 countries 2016 (vertical) and 1996 (horizontal). Source: Own calculations

Fig. 11 Human development index development 1996-2015 Source: UNDP. Note: RoW, rest of World

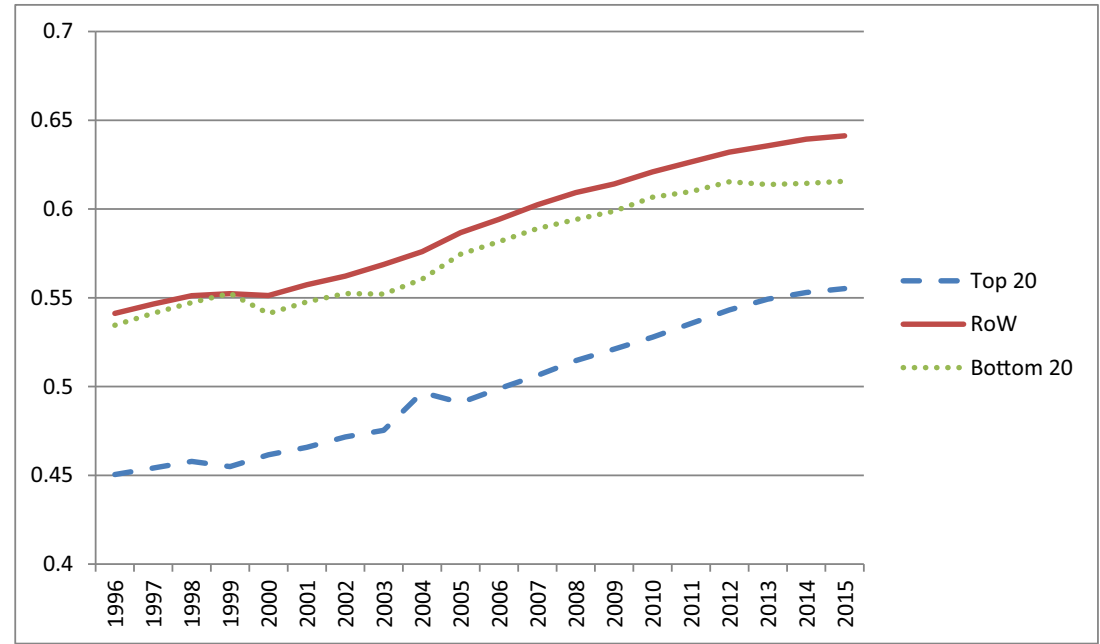


Fig. 12 Percentage change in Human Development Index in low- and lower middle SubSaharan African economies Source: McMahon and Moreira

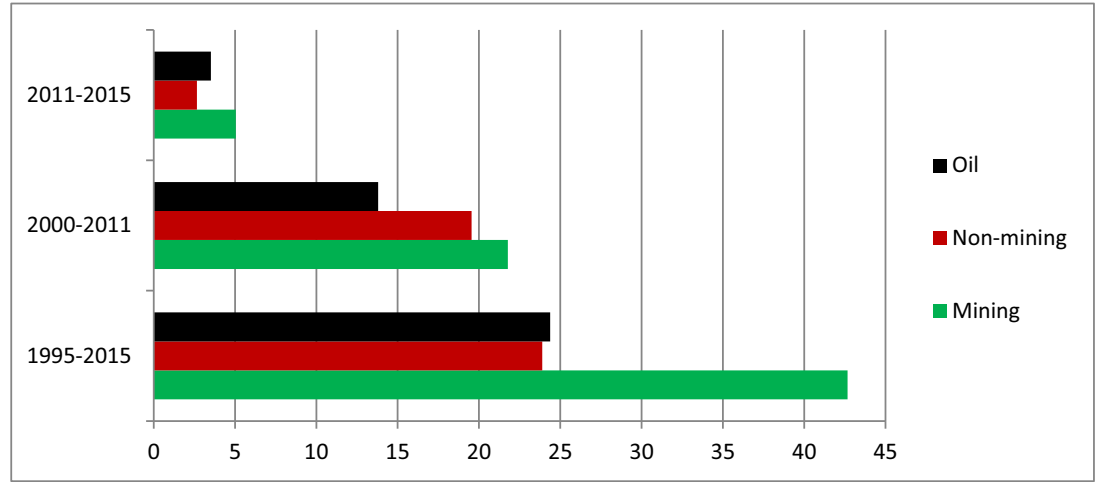

share of mineral exports in total exports of those countries increased by $50 \%$ in the same period. Exploration spending in the countries studied increased over the period as a whole, but has been declining steeply since 2013. Mineral rents followed the general metal price developments and reached a peak in 2011, but have declined since, although they are still higher in 2016 than they were in the 1990s. Several LIE and MIE countries with high MCI-Wr scores in 1996 have developed successfully and risen in the World Bank classification from LIE to MIE, from LMIE to UMIE and from UMIE to HIE.

Figure 10 shows the MCI-Wr scores of the top 50 countries in 2016 relative to the situation in 1996. In countries above the line, mining's contribution to national economies has increased and below the line they have decreased. The quick growth in Eritrea, Lesotho and Cote d'Ivoire is clearly visible. A range of other countries has also seen mining's contribution to their national economic development increase.

As can be seen from the graph for those countries where mining's contribution has dropped between 1996 and 2016, the decline has been much smaller (closer to the line) than the growth countries which are scattered further away from the line. Among the countries below the line, where mining's contribution has dropped two groups is identifiable: former centrally planned economies such as Russia, Kazakhstan and Tajikistan and some of the largest mining countries such as Brazil, Australia, Canada and South Africa. Even Botswana and Chile, two countries which have been considered to be successful in using mining as a lever for economic development, are above the line i.e. mining's contribution to their national economies has increased during the period. ${ }^{20}$

\footnotetext{
${ }^{20}$ Lange G.-M., Wodon Q. and Carey K. 'The Changing Wealth of Nations 2018', World Bank 2018, pp. 11 and 75.
}

\section{Social development and mining}

The analysis of the contribution of mining to national economies and to development can be taken a step further to include a number of indicators of social development:

- Human Development Index (HDI).

- Governance including: corruption, political stability, rule of law, government effectiveness, regulatory quality, voice and accountability.

- Inequality, the Gini coefficient. ${ }^{21}$

\section{Human development index}

Human development index (HDI) as defined by the United Nations measures several aspects of social development such as health, life expectancy, standard of living, education. The top 20 economies in the MCI-Wr index have increased their HDI on average from 0.45 to about 0.55 , an increase with $27 \%$. It is notable that the top $20 \mathrm{MCI}-\mathrm{Wr}$ group of countries has managed to develop at the same pace in this period as have the rest of world group (RoW) including most high-income countries. By contrast, the bottom 20 economies in the MCI-Wr index have increased slightly less, $18 \%$ between the years 1996-2015 (Fig. 11).

To get a closer look into the social development the analysis has focused on Sub-Saharan Africa, which has been chosen for a first more detailed analysis of social developments in mining countries using existing indicators over the 20 -year period from 1996 to 2015. The countries of sub-Saharan Africa were divided into three groups (see Figs. 12 and 13) oil producing countries, mining countries and non-mining countries (countries with neither minerals nor oil production) and the development of Human Development Index and some indicators of governance where compared. In both figures mining countries are

\footnotetext{
${ }^{21}$ The Gini coefficient is not updated every year for all countries in World Bank or UNU WIDER World Income Inequality Database and in those cases, the years 1996 and 2014 were not available, closest year has been selected.
} 
Fig. 13 Percentage change in Governance indicators in lowand lower middle sub-Sahara Africa economies 1996-2015 Source: McMahon and Moreira

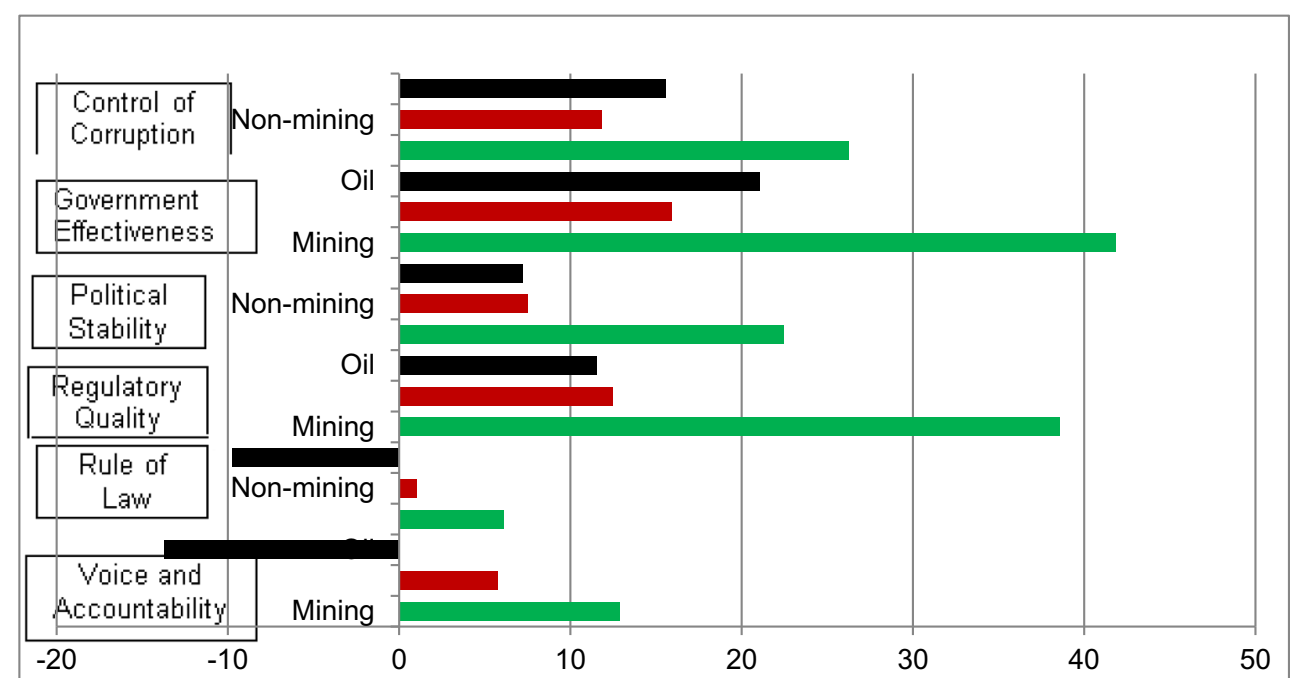

shown in green, oil producing countries in black and nonmining countries in red. In mining countries in the region, HDI has risen by $43 \%$, while in non-mining countries with only $24 \%$ and the same figure in oil producing countries.

Mining countries: Burkina Faso, DRC, Cote d'Ivoire, Eritrea, Ghana, Guinea, Liberia, Madagascar, Mali, Mauritania, Mozambique, Namibia, Niger, Rwanda, Senegal, Sierra Leone, Tanzania, Togo, Zambia, Zimbabwe. Non-mining countries: Central African Rep., Ethiopia, Lesotho, Benin, Burundi, Cabo Verde, Djibouti, Gambia, Guinea-Bissau, Kenya, Malawi, Somalia, Swaziland, Uganda. Oil countries: Angola, Sudan, Cameroon, Congo, Rep. Equatorial Guinea, Nigeria, South Sudan and Chad

\section{Governance indices}

Measured with a set of governance indicators (corruption, effectiveness, political stability, regulatory quality, rule of law and voice and accountability), mining countries have developed significantly better than non-mining countries and oil producing countries. In oil producing countries the indicators rule of law and voice and accountability even show a situation in 2015, which is worse than it was in 1996.

\section{Inequalities and Gini coefficient}

The development of the Gini coefficient in the 20 low- and middle-income countries with the highest MCI-Wr ranking in 1996 over a period until the mid-2010s is shown in Table 10. The Gini coefficient is not calculated for all countries for every year and hence the comparison cannot be made for the same year for all the countries. The Gini coefficient, i.e. inequality, has been constant or decreased in 13 countries and increased only in four countries. This is a first and preliminary indication that inequality, as measured by the Gini coefficient, is not necessarily directly linked to development of mining in LIE and MIE countries.

To conclude this brief and introductory statistical survey of social indicators in mining countries, particularly in Africa, there are indications that economic development in the mining sector does not automatically mean a deterioration or slowdown of social development. The World Bank report 'The Contribution of the Mining Sector to Socioeconomic and Human Development ${ }^{\text {,2 }}$ and ICMM's 'Social progress in mining-dependent countries' give further examples and discuss these issues in more detail.

\section{Future developments of the contribution of mining}

The present metal and mineral price cycle bottomed out during 2016 and a recovery has been taking place since then. Metal and mineral prices have fallen since the peaks of 2011, but prices are well above the levels of the late 1990s and early 2000s before the 'super cycle' kicked in. As Fig. 14 shows, the price index has been on a downward trend since 2011 with a flattening in 2016 and increase in 2017 and the beginning of 2018. During the years of decline (2012-2016), prices were always at relatively high levels on average 2-3 times higher than in the period preceding the 'super cycle'. Even copper and nickel, which experienced the deepest dip, bottomed out in 2016 at levels above where they were in the end of the 1990s. Non-ferrous exploration expenditure dropped to 7300 MUSD in 2016, only a third of the 2012 level. In 2017, there was a strong recovery in prices, which has continued into 2018. Exploration increased by $15 \%$ in $2017 .^{23}$ Investments into new mines remain however at low levels.

\footnotetext{
${ }^{22}$ McMahon, Gary; Moreira, Susana. 2014. The Contribution of the Mining Sector to Socioeconomic and Human Development. Extractive industries for development series; no. 30. World Bank, Washington, DC.

${ }^{23}$ S\&P Global, World Exploration Trends, 2018. This is the same source as the one previously cited SNL Metals \& Mining World Exploration Trends.
} 
Table 10 Gini coefficient in Top 20 mining countries in the early 1990s compared to $2000 / 2010$ s

\begin{tabular}{llllll}
\hline MCI-Wr top 20, 2016 & Gini & Year & Gini & Year & $+/-$ \\
\hline Botswana & 48.5 & 1994 & 48.1 & 2010 & -0.4 \\
Chile & 56.43 & 1994 & 50.45 & 2013 & -5.98 \\
Congo, Dem. Rep. & 42.16 & 2004 & 42.1 & 2012 & -0.06 \\
Eritrea & - & - & - & - & - \\
Ghana & 40.07 & 1997 & 42.77 & 2005 & 2.7 \\
Guinea & 46.08 & 1994 & 33.73 & 2012 & -12.35 \\
Guyana & 52.8 & 1993 & 35 & 2006 & -17.8 \\
Kazakhstan & 32.67 & 1993 & 26.33 & 2013 & -6.34 \\
Kyrgyz Republic & 31.04 & 2000 & 26.82 & 2014 & -4.22 \\
Lao PDR & 34.9 & 1997 & 37.89 & 2012 & 2.99 \\
Liberia & - & - & 36.48 & 2007 & - \\
Mauritania & 50.05 & 1993 & 32.42 & 2014 & -17.63 \\
Mongolia & 33.2 & 1995 & 32.04 & 2014 & -1.16 \\
Namibia & 74.3 & 1993 & 59.7 & 2010 & -14.6 \\
Papua New Guinea & 50.9 & 1996 & 43.88 & 2009 & -7.02 \\
Peru & 44.02 & 1994 & 44.14 & 2014 & 0.12 \\
Sierra Leone & 40.17 & 2003 & 33.99 & 2011 & -6.18 \\
Suriname & 57.61 & 1999 & - & - & - \\
Tanzania & 38.1 & 1993 & 37.78 & 2011 & -0.32 \\
Zambia & 52.61 & 1993 & 55.62 & 2010 & 3.01 \\
\hline
\end{tabular}

Source: World Bank Data, UNU-WIDER

Demand for metals and minerals in general has not dropped, rather it stays at the same levels as before and continues to increase slowly but steadily. There are some indications that the price trough is generated by an over-supply situation rather than by a fall in demand. ${ }^{24}$ Gradual improvements in standard of living, increased life expectancy and continuing urbanization, remain in force and together they form the major longterm drivers of metal and mineral use. ${ }^{25}$ On top of this, continuing, slow and gradual increase in metal demand the urgent switch to fossil free electricity and energy supply will dramatically increase demand for most metals and minerals. Increased recycling will not change this situation in the short term but will affect mid-term scenarios and might double the growth rates previously projected. ${ }^{26}$

One of the major reasons for the 'super cycle' was the slow supply response of the mining industry to increased demand. ${ }^{27} \mathrm{It}$ takes a minimum 3-5 years to increase capacity in an existing mine and 10-15 years for a green field project to start producing. This time lag is further continuously increasing due to several factors: increasing advantages of scale economies, i.e. bigger mines with larger investments, longer and more difficult permitting processes depending on more stringent societal demands and regulations and increasing opposition by local residents

\footnotetext{
${ }^{24}$ See for example: Tim Worstall, Rio Tinto and Vale killed the commodities 'super cycle' not China or the Fed, Forbes 29th November 2015.

${ }^{25}$ McKinsey Global Institute, Reverse the curse: Maximizing the potential of resource-driven economies, December 2013.

${ }^{26}$ World Bank/International Bank for Reconstruction and Development, The Growing Role of Minerals and Metals for a Low Carbon Future, Washington, DC 2017.

${ }^{27}$ This paragraph is largely based on David Humphreys, The Remaking of the Mining Industry, Palgrave MacMillan 2015.
}

(NIMBY). The global mining industry might be facing a similar situation during the 2020s as it did in the early 2000s: slowly increasing demand but hesitancy about investing and low supply elasticity in response to demand. There are at present no indications of a new 'super cycle'; nevertheless, at some point, metal prices might shoot up again when supply and demand does not meet any longer. ${ }^{28}$ The situation could be exacerbated by the lack of exploration during the past years and also the swinging popular sentiments towards mining as well as restricted access to the most prospective countries because of war and politics.

As can also be seen from Fig. 14, mineral prices are one important but not the sole determinant of the changing levels of exports, value of mine production, mineral rents and exploration expenditures also play an important role.

\section{Conclusions}

\section{Contribution of mining to national economies}

There are 14 low-income countries, 33 middle-income countries and 3 high-income countries among the 50 countries with the highest MCI-Wr score in 2016. It is obvious that mining plays an important role particularly in many low- and middle-income countries. Among the top 20 countries, Congo (DRC) has the highest score followed by Burkina Faso, Mali, Papua New Guinea and Eritrea. Chile and Australia show that also in some high-income countries, mining remains a vital part of the national economy. African economies are dominating among the top 20 countries, with 12 countries. The African mining vision of metals and minerals as important parts of African economic and social development is clearly well founded.

\section{Change in contribution over the past 20 years}

Eleven economies have climbed up one step on the GNI development classification, to lower middle, upper middle or highincome category among the 20 low- and middle-income countries with the highest MCI-Wr score in 1996. There are certainly many drivers contributing to this development but mining is one important factor. Geographically, Africa, in its entirety, and in particular West Africa is a good example of economic development of mineral-producing countries.

The figures for both GDP and export share of metals and minerals are considerably higher on average for the LIEs than for the MIEs. The levels of GDP and export contributions in 2016 are still at a higher level than in 1996 in spite of the poor development of metal prices since the end of the 'super cycle'.

\footnotetext{
${ }^{28}$ See for example: Kip Atkinson Keen, Next upswing in metal prices inevitable with few quality mines coming online, S\&P Global Market Intelligence 7 September 2016.
} 


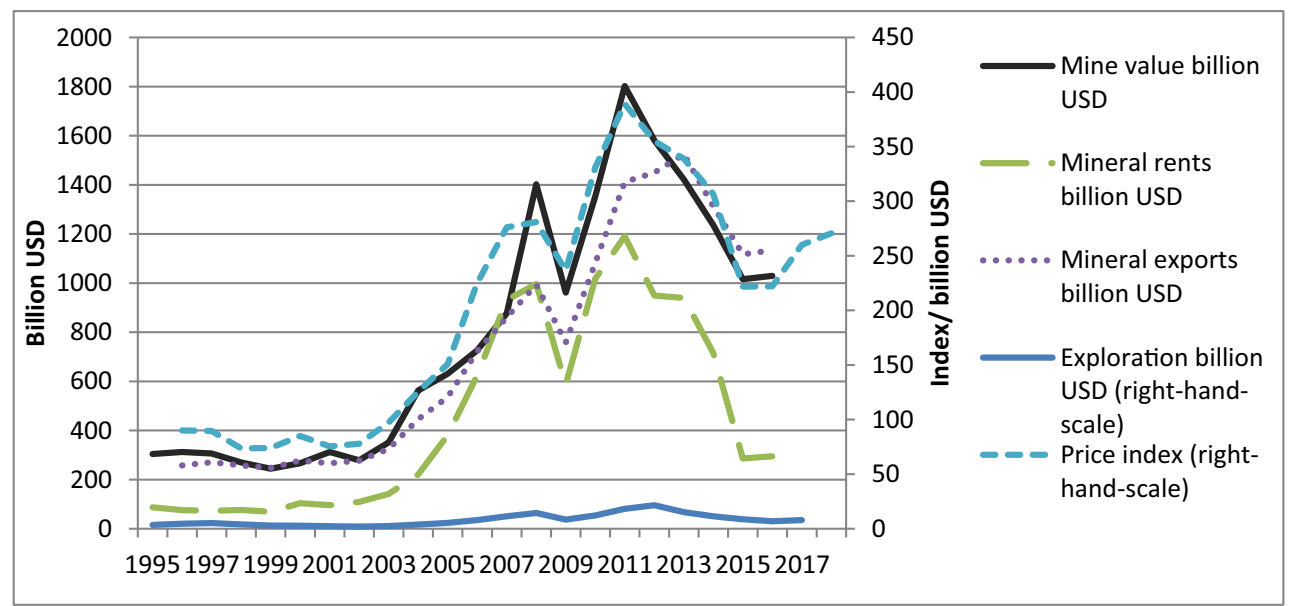

Fig. 14 Mining development trends 1995-2018: prices, exports, exploration, value of mine production, mineral rents Sources: Raw Materials Data, World Bank, SNL Metals \& Mining, UNCTAD 2016. Note: The price index includes copper, gold, iron ore, nickel and zinc. The weighting on the price index was calculated as an average based on the

The MCI-Wr index for individual countries has moved up and down depending on the performance of their mining sector relative to other sectors of the economy and on the global metal market trends. It is difficult to draw conclusions from these changes over time as the relative MCI-Wr index. There is a need to further develop the contribution index to deal with this issue.

\section{Impact of the end of the 'super cycle'}

Mining's contribution to GDP and exports reached a maximum at the height of the 'super cycle' in 2011. The figures for mining's contribution have declined for most countries by 2016 but the levels were still considerably higher than in 1996.

\section{Socio-economic impacts}

There are many reasons why mineral-rich countries developed during this period, and certainly not only because of mining activities and rich mineral resources. Nevertheless, the statistical conclusion from the 2014 MCI-W study is confirmed by this update including also socio-economic indicators. Mining can trigger and have triggered development in several countries. When the analysis is expanded to include also how the GINI coefficient has developed in the mineral-rich countries, it further seems as if inequalities have decreased. In this sample of the $20 \mathrm{LIE}$ and MIE countries with the highest MCI-Wr scores in 1996, the GINI coefficient has remained constant or decreased, i.e. inequalities diminished in 13 countries and increased in 4 countries. HDI has increased in mining countries with $43 \%$ between 1995 and 2015. African mining countries have done better than African oil-producing countries. contribution of each metal to the total value of all metal and mineral (excluding non-fuel minerals and cola) products of mining industry. The weighting was used to combine the price development of different metals and minerals into one index. 1995 is the base year for the index. All prices are in nominal dollars.

\section{Contribution or dependency?}

'Contribution' or 'dependency' — already by choosing the words to describe the relationship between national economies and the extractive sector a fundamental choice is made between good or bad. The traditional and current perspective, in many high-income countries rich in mineral resources, such as Canada, Sweden, the USA and other countries, is that mineral resources are and have been fountains out of which wealth flow and development grow. It is clear that 'resource-rich countries have an apparent advantage over other countries because they have a source of revenue with which to finance investment and development', but on the other hand 'managing the windfall from resource rents poses well-known challenges for macroeconomic management'. ${ }^{29}$ During the late 1900s until recently, the dependency approach was dominating norm claiming that abundance of mineral resources hinders economic development rather than facilitating it. ${ }^{30}$ The resource curse paradigm was another starting point for critical analysis. ${ }^{31}$ During and after the 'super cycle', with high metal and oil prices, this a priori negative starting point was beginning to be questioned. ${ }^{32,33,34}$

\footnotetext{
${ }^{29}$ Lange, Wodon and Carey 2018, p. 82.

${ }^{30}$ For a discussion and definition of resource dependency see for example Lange, Wodon and Carey op. cit. and ICMM 2018 pp. 12-13.

${ }^{31}$ For an extended discussion of the resource curse please see Nülle and Davis Neither Dutch nor disease?-natural resource booms in theory and empirics, Mineral Economics 2018, 31 pp. 35-59.

${ }^{32}$ This turnaround is described and analysed more deeply in the introductory chapter by Tony Addison and Alan Roe in the Extractive Industries: The Management of Resources as a Driver of Sustainable Development.

${ }^{33}$ McKinsey Global Institute, Reverse the curse: Maximizing the potential of resource-driven economies, December 2013.

${ }^{34}$ Ana Elizabeth Bastida. Editor, Can mining be a catalyst for diversifying economies?, special issue of Mineral Economics Vol 27, numbers 2-3 December 2014.
} 
The results of this survey do not support the widespread view that mineral resources create a dependency which might not be conducive to economic and social development. Rather the opposite - if more LIE and MIE were rich in non-fuel minerals their chances of economic development and possibly also socio-economic progress would have been better than they are at present when only limited non-fuel mineral resources are known. Certainly, the four indicators on which we base our study only shed light on some aspects of economic and social development. But we think we have enough substance to claim that if additional LIE and MIE countries could localize new mineral resources, their chances of economic development would improve. It remains important for mining countries not to focus too much on mineral and metal prices in the short term but to maintain a steady approach and stick to their long-term strategies for development of their national mineral resources, their management and also diversification opportunities should they appear. A continued and growing supply of metals and minerals will be particularly important in the transition to a fossil-free future and this additional demand for metals and minerals could be turned into economic and social development in mineral-rich emerging economies.

\section{Appendix 1}

\begin{tabular}{|c|c|c|c|c|c|c|c|c|c|c|c|c|c|c|c|c|c|c|c|}
\hline \multirow[b]{2}{*}{ Year } & \multicolumn{3}{|c|}{$\begin{array}{c}\% \text { of total } \\
\text { export }\end{array}$} & \multicolumn{3}{|c|}{$\begin{array}{c}\text { Production value } \% \\
\text { of GDP }\end{array}$} & \multicolumn{3}{|c|}{$\begin{array}{c}\text { Exploration } \% \text { of } \\
\text { value }\end{array}$} & \multicolumn{3}{|c|}{$\begin{array}{c}\text { Mineral rents (\% } \\
\text { of GDP) }\end{array}$} & \multicolumn{4}{|c|}{ MCl-score } & \multicolumn{3}{|c|}{ MCl Rank } \\
\hline & 1996 & 2014 & 2016 & 1996 & 2014 & 2016 & 1996 & 2014 & 2016 & 1996 & 2014 & 2016 & 1996 & 2014 & 2015 & 2016 & 1996 & 2014 & 2016 \\
\hline Congo, Dem. Rep. & 72.4 & 80.9 & 86.0 & 7.73 & 14.7 & 11.6 & 0 & 3.98 & 2.1 & 1.04 & 18.4 & 13.2 & 72.2 & 93.3 & 92.8 & 93 & 29 & 1 & 1 \\
\hline Burkina Faso & 7.7 & 49.6 & 78.3 & 0.32 & 6.01 & 5.89 & 104 & 9.27 & 4.04 & 0 & 8.78 & 10.3 & 55.6 & 90.8 & 91.9 & 92.9 & 64 & 5 & 2 \\
\hline Mali & 8.3 & 65.7 & 74.7 & 0.92 & 5.28 & 5.68 & 25.9 & 4.01 & 3.49 & 0 & 7.97 & 8.97 & 59.4 & 87.9 & 90.4 & 91.6 & 57 & 9 & 3 \\
\hline Papua New Guinea & 24.5 & 37.9 & 39.2 & 8.95 & 14 & 10.2 & 3.35 & 5.91 & 3.22 & 12.4 & 10.9 & 11.3 & 89.5 & 92 & 89.9 & 91.1 & 3 & 3 & 4 \\
\hline Eritrea & 62.8 & 38.6 & 54.5 & 0 & 7.22 & 3.44 & & 4.99 & 4.69 & 0 & 14.3 & 6.8 & 24.4 & 89.9 & 90.4 & 90.3 & 119 & 7 & 5 \\
\hline Namibia & 38.3 & 50.3 & 58.6 & 1.91 & 6.91 & 6.11 & 2.23 & 3.83 & 2.47 & 0.41 & 6.49 & 6.68 & 83.5 & 87.3 & 89.3 & 90.1 & 11 & 10 & 6 \\
\hline Mauritania & 35.9 & 58.1 & 50.7 & 4.44 & 10.2 & 7.89 & 0.8 & 1.55 & 1.61 & 5.78 & 27.6 & 22.3 & 84.9 & 86.8 & 87.6 & 89.5 & 9 & 13 & 7 \\
\hline Suriname & 68.8 & 33.8 & 38.4 & 1.84 & 5.98 & 7.14 & 9.52 & 3.66 & 2.33 & 0 & 16.2 & 24.0 & 66.5 & 85.6 & 93.6 & 89.3 & 42 & 16 & 8 \\
\hline Peru & 48.3 & 53.8 & 61.0 & 1.82 & 5.76 & 6.02 & 5.63 & 2.74 & 1.86 & 0.51 & 6.15 & 6.72 & 86.7 & 84.8 & 87.3 & 88.3 & 8 & 17 & 9 \\
\hline Liberia & 49.3 & 39.3 & 32.3 & 1.08 & 11.3 & 6.05 & 0 & 4.67 & 2.43 & 9.26 & 22.1 & 17.6 & 67.6 & 92 & 92.1 & 88.2 & 37 & 4 & 10 \\
\hline Botswana & 80.9 & 91.3 & 92.7 & 9 & 12.8 & 9.09 & 0.23 & 1.13 & 1.11 & 0.45 & 12 & 7.48 & 83.8 & 86.2 & 87.2 & 88.2 & 10 & 15 & 11 \\
\hline Chile & 47.7 & 57.0 & 51.9 & 3.45 & 9.52 & 7.04 & 2.29 & 1.91 & 1.55 & 6.14 & 14 & 9.84 & 88.6 & 86.9 & 88.1 & 87.8 & 4 & 11 & 12 \\
\hline Zambia & 75.9 & 75.1 & 75.0 & 3.59 & 7.58 & 5.52 & 1.42 & 2.79 & 1.4 & 3.87 & 12.7 & 10.9 & 87.5 & 88.6 & 89.5 & 87.3 & 5 & 8 & 13 \\
\hline Guyana & 37.4 & 61.2 & 59.6 & 6.34 & 10.5 & 18 & 3.99 & 5.34 & 0.81 & 5.55 & 10.6 & 11.8 & 90.8 & 93 & 90.4 & 87.2 & 2 & 2 & 14 \\
\hline Sierra Leone & 27.8 & 93.6 & 88.2 & 0.51 & 14.9 & 6.03 & 5.66 & 1.76 & 1.1 & 0.04 & 18.1 & 9.89 & 77.2 & 89.9 & 87.5 & 87.1 & 19 & 6 & 15 \\
\hline Mongolia & 57.5 & 80.4 & 82.5 & 5.55 & 16.7 & 14.7 & 0 & 0.99 & 0.48 & 9.68 & 21.1 & 21.5 & 72.8 & 86.9 & 86.8 & 86 & 27 & 12 & 16 \\
\hline Australia & 34.7 & 56.7 & 54.9 & 4.37 & 11.9 & 10.1 & 2.68 & 1.04 & 0.83 & 1.09 & 6.46 & 5.01 & 87.4 & 83.3 & 83.7 & 84.6 & 6 & 18 & 17 \\
\hline Guinea & 76.3 & 52.1 & 61.6 & 5.81 & 8.81 & 9.79 & 3.33 & 2.65 & 0.56 & 5.17 & 7.49 & 9.76 & 91.7 & 86.8 & 86.3 & 84.3 & 1 & 14 & 18 \\
\hline Tanzania & 3.9 & 38.1 & 44.5 & 0.19 & 1.47 & 1.47 & 34.9 & 5.4 & 3.26 & 0.02 & 2.5 & 2.97 & 66.9 & 80.5 & 81.5 & 83.4 & 41 & 19 & 19 \\
\hline Kyrgyz Republic & 7.1 & 28.5 & 47.8 & 0.85 & 4.72 & 5.34 & 6.95 & 1.8 & 1.09 & 0.22 & 7.07 & 8.23 & 77 & 80 & 83.8 & 83.2 & 20 & 20 & 20 \\
\hline Ghana & 28.4 & 23.0 & 36.4 & 1.87 & 4.07 & 5.26 & 6.33 & 2.11 & 1.11 & 1.09 & 6.47 & 6.08 & 86.7 & 79.2 & 81.9 & 81.6 & 7 & 23 & 21 \\
\hline Lao PDR & 1.5 & 36.5 & 32.7 & 0.03 & 3.25 & 2.59 & 43 & 2.91 & 1.48 & 0 & 8.16 & 5.63 & 53.7 & 59.1 & 60.9 & 81.2 & 69 & 61 & 22 \\
\hline Senegal & 9.9 & 15.9 & 20.3 & 0.52 & 1.06 & 1.43 & 15.7 & 14.4 & 8.35 & 0 & 1.58 & 1.77 & 57.9 & 76.1 & 80 & 81 & 61 & 24 & 23 \\
\hline Bolivia & 31.0 & 27.4 & 40.1 & 1.13 & 5.59 & 3.64 & 6.87 & 0.48 & 1.16 & 0.01 & 3.51 & 2.75 & 78.9 & 73.3 & 82.4 & 80.9 & 18 & 32 & 24 \\
\hline Armenia & 24.1 & 47.3 & 50.6 & 0.14 & 2.29 & 2.76 & 0 & 1.23 & 1.05 & 0.47 & 3.32 & 4.6 & 53.2 & 76.1 & 84.1 & 80.8 & 71 & 25 & 25 \\
\hline Zimbabwe & 15.9 & 20.1 & 41.1 & 2.18 & 9.85 & 7.2 & 1.38 & 0.55 & 0.43 & 4.32 & 4.45 & 4.62 & 81.9 & 75.8 & 75.7 & 79.1 & 15 & 26 & 26 \\
\hline Mozambique & 6.4 & 51.1 & 51.9 & 0.15 & 2.9 & 1.64 & 0.89 & 2.99 & 1.03 & 0.01 & 1.39 & 2.32 & 58.9 & 80 & 83.5 & 78.2 & 59 & 21 & 27 \\
\hline Uzbekistan & 9.9 & 30.5 & 47.6 & 2.37 & 3.09 & 2.65 & 0.1 & 0.6 & 0.43 & 1.65 & 5.5 & 5.1 & 76.1 & 73.8 & 75.2 & 76.5 & 22 & 31 & 28 \\
\hline
\end{tabular}




\begin{tabular}{|c|c|c|c|c|c|c|c|c|c|c|c|c|c|c|c|c|c|c|c|}
\hline Canada & 8.3 & 11.4 & 11.0 & 1.122 & 2.174 & 1.864 & 4.27 & 4.48 & 3.32 & 0.44 & 0.78 & 0.7 & 79.06 & 74.28 & 75.8 & 75.89 & 17 & 30 & 29 \\
\hline South Africa & 35.9 & 38.2 & 35.2 & 4.829 & 7.067 & 5.899 & 0.37 & 0.41 & 0.24 & 2.96 & 5.1 & 4.59 & 82.65 & 75.33 & 76.28 & 75.06 & 13 & 28 & 30 \\
\hline Madagascar & 8.0 & 37.4 & 27.0 & 0.61 & 2.061 & 1.509 & 2.23 & 0.54 & 1.24 & 0 & 3.41 & 1.33 & 67.67 & 71.29 & 75.88 & 75.06 & 36 & 34 & 31 \\
\hline ajikistan & .2 & 59.1 & 54.7 & 0.364 & 1.898 & 2.369 & 18.6 & 1.13 & 0.24 & 0.27 & 1.74 & 2.98 & 80.37 & 74.78 & 75.98 & 75.03 & 16 & 29 & 32 \\
\hline Cote d'Ivoire & 0.7 & 5.8 & 6.1 & 0.052 & 1.001 & 1.326 & 18.6 & 7.19 & 4.51 & 0 & 1.4 & 2.42 & 36.3 & 69.9 & 73.09 & 74.53 & 102 & 38 & 33 \\
\hline Colombia & 12.1 & 16.6 & 21.5 & 0.496 & 1.645 & 1.384 & 0.18 & 1.84 & 1.41 & 0.11 & 1.12 & 1.16 & 67.58 & 70.93 & 74.29 & 73.89 & 38 & 35 & 34 \\
\hline iji & 9.2 & 6.4 & 8.1 & 1.037 & 0.64 & 0.872 & 15.9 & 18.9 & 9.07 & 1.05 & 0.9 & 0.95 & 82.77 & 68.68 & 74.06 & 73.62 & 12 & 42 & 35 \\
\hline Niger & 21.3 & 29.1 & 30.0 & 0.176 & 0.291 & 0.326 & 81.9 & 51.4 & 3.25 & 0.13 & 0.29 & 0.42 & 76.54 & 70.04 & 75.24 & 72.64 & 21 & 37 & 36 \\
\hline Kazakhsta & 26.2 & 10.0 & 16.5 & 3.23 & 4.181 & 4.185 & 0.82 & 0.71 & 0.38 & 2.18 & 3.05 & 4.1 & 82.28 & 69.82 & 71.25 & 72.3 & 14 & 39 & 37 \\
\hline Lesotho & 3.5 & 26.4 & 22.3 & 0 & 6.382 & 6.045 & & 1.68 & 0.05 & 0 & 6.33 & 5.96 & 14.45 & 79.83 & 71.87 & 71.9 & 140 & 22 & 38 \\
\hline Jamaica & 49.7 & 48.1 & 46.3 & 1.194 & 1.238 & 1.055 & 0 & 1.3 & 0.56 & 2.89 & 0.95 & 1.05 & 67.45 & 70.05 & 75.05 & 71.87 & 39 & 36 & 39 \\
\hline Nicaragu & 1.8 & 8.3 & 7.9 & 0.214 & 1.113 & 1.173 & 37.5 & 3.62 & 1.88 & 0.05 & 2.03 & 1.93 & 65.22 & 69.43 & 73.84 & 71.52 & 44 & 40 & 40 \\
\hline udan & 4.2 & 27.4 & 26.9 & 0.091 & 1.864 & 2.315 & 0 & 0.54 & 0.14 & 0.07 & 2.45 & 2.91 & 42.54 & 68.83 & 71.16 & 69.74 & 91 & 41 & 41 \\
\hline Brazil & 11.5 & 16.3 & 13.1 & 0.391 & 1.327 & 1.254 & 1.74 & 0.74 & 0.66 & 0.31 & 1.69 & 1.37 & 73.04 & 65.92 & 68.56 & 68.54 & 26 & 46 & 42 \\
\hline Dominican Republic & 1.5 & 20.0 & 20.2 & 0.339 & 1.242 & 1.617 & 1.56 & 0.41 & 0.33 & 0.67 & 1.94 & 1.77 & 61.75 & 63.7 & 66.52 & 68.51 & 52 & 52 & 43 \\
\hline Russian F & .2 & 8.7 & 11.7 & 1.008 & 1.889 & 1.704 & 0.1 & 0.81 & 0.53 & 0.47 & 1.11 & 1.37 & 71.86 & 64.88 & 67.65 & 68.5 & 31 & 50 & 44 \\
\hline Macedonia, FYR & 9.6 & 5.2 & 3.9 & 2.281 & 3.03 & 1.897 & 0 & 1.6 & 1.73 & 0.39 & 2.88 & 1.37 & 62.6 & 68.53 & 68.53 & 68.42 & 50 & 43 & 45 \\
\hline Togo & 32.8 & 30.5 & 27.9 & 1.54 & 9.684 & 6.326 & 0.46 & 0.14 & 0 & 0 & 14.6 & 11.9 & 55.32 & 75.51 & 75.58 & 68.12 & 65 & 27 & 46 \\
\hline Gabon & 4.0 & 6.0 & 5.4 & 0.256 & 1.995 & 2.115 & 0.7 & 3.83 & 1.76 & 0 & 0.15 & 0.31 & 56.66 & 66.19 & 68.19 & 67.81 & 62 & 45 & 47 \\
\hline Philippines & 4.2 & 7.7 & 5.8 & 0.154 & 0.99 & 0.575 & 10.6 & 2.16 & 2.46 & 0.33 & 2.32 & 0.98 & 68.72 & 66.42 & 67.19 & 67.78 & 35 & 44 & 48 \\
\hline Solomon Islands & 0.1 & 3.5 & 2.3 & 0 & 1.533 & 0.537 & & 37 & 99 & 0.01 & 3.33 & 2.97 & 18.56 & 72.36 & 68.79 & 67.76 & 132 & 33 & 49 \\
\hline Argentina & 1.2 & 6.0 & 6.8 & 0.018 & 0.555 & 0.48 & 80.3 & 3.51 & 3.61 & 0 & 0.41 & 0.37 & 52.06 & 59.95 & 65.36 & 67.33 & 75 & 59 & 50 \\
\hline Afghanistan & 1.4 & 18.2 & $27.2-$ & & 0.002 & 0.002 & 0 & 0 & 198 & 0 & 0.22 & 0.18 & 9.141 & 36.84 & 65.12 & 67.12 & 158 & 114 & 51 \\
\hline Serbia & 14.9 & 5.8 & 5.2 & 2.76 & 3.037 & 2.868 & 0 & 1.52 & 1.09 & 0.08 & 0.67 & 0.55 & 62.32 & 65.52 & 66.11 & 66.4 & 51 & 48 & 52 \\
\hline Georgia & 8.1 & 12.2 & 21.7 & 0.069 & 0.784 & 0.844 & 0 & 0 & 0.48 & 0.14 & 0.82 & 0.74 & 46.09 & 48.79 & 62.71 & 66.1 & 86 & 87 & 53 \\
\hline Honduras & 1.7 & 6.4 & 6.9 & 0.148 & 0.59 & 0.381 & 1.39 & 1.55 & 2.3 & 0.11 & 0.74 & 0.59 & 55.17 & 58.21 & 58.56 & 65.64 & 67 & 63 & 54 \\
\hline Mexico & 2.3 & 4.0 & 4.1 & 0.241 & 0.819 & 0.765 & 4.7 & 4.24 & 2.44 & 0.13 & 0.74 & 0.86 & 64.01 & 63.33 & 65.22 & 65.49 & 46 & 54 & 55 \\
\hline Bulgaria & 9.8 & 14.8 & 11.6 & 2.143 & 3.025 & 2.421 & 0.07 & 0.11 & 0.2 & 1.41 & 1.3 & 1.08 & 74.78 & 63.62 & 65.42 & 65.4 & 24 & 53 & 56 \\
\hline Indonesia & 8.1 & 16.3 & 15.7 & 0.364 & 1.625 & 1.374 & 4.12 & 0.43 & 0.18 & 0.76 & 1.68 & 1.19 & 75.11 & 64.6 & 67.67 & 64.65 & 23 & 51 & 57 \\
\hline & & 9 & 7 & & & & & 57 & 15 & & 175 & 0 & 523 & 1547 & & 391 & 56 & & \\
\hline
\end{tabular}




\begin{tabular}{|c|c|c|c|c|c|c|c|c|c|c|c|c|c|c|c|c|c|c|c|}
\hline Congo, Rep. & 1.9 & 10.3 & 12.1 & 0 & 0.002 & 0.025 & & 1412 & 69.8 & 0.04 & 0.03 & 0.05 & 29.67 & 56.35 & 64.56 & 63.87 & 112 & 67 & 59 \\
\hline Finland & 3.2 & 5.7 & 5.4 & 0.136 & 0.719 & 0.564 & 0.2 & 4.07 & 2.4 & 0.01 & 0.29 & 0.22 & 51.34 & 61.53 & 66.06 & 63.73 & 76 & 56 & 60 \\
\hline Ukraine & 8.9 & 11.3 & 9.7 & 1.937 & 2.921 & 2.025 & 0.02 & 0 & 0.01 & 0.69 & 3.45 & 2 & 72.17 & 62.45 & 63.71 & 63.03 & 30 & 55 & 61 \\
\hline Guatemal & 0.6 & 8.0 & 6.7 & 0 & 1.065 & 0.849 & & 2.21 & 0.73 & 0 & 1.07 & 0.64 & 6.538 & 65.86 & 66.15 & 62.48 & 171 & 47 & 62 \\
\hline Sweden & 2.9 & 5.1 & 4.5 & 0.337 & 0.789 & 0.706 & 1.99 & .11 & 1.67 & 0.03 & 0.46 & 0.2 & 61.51 & 59.25 & 59.99 & 61.44 & 53 & 60 & 63 \\
\hline India & 16.2 & 11.7 & 14.3 & 0.719 & 0.879 & 0.771 & 0.01 & 0.1 & 0.08 & 0.98 & 1.49 & 1.14 & 71.06 & 56.8 & 61.51 & 60.88 & 32 & 66 & 64 \\
\hline Turkey & 2.5 & 6.1 & 9.5 & 0.457 & 0.931 & 0.562 & 0.34 & 0.66 & 0.67 & 0.04 & 0.26 & 0.21 & 58.19 & 54.48 & 59.43 & 60.84 & 60 & 72 & 65 \\
\hline Ecuador & 2.8 & 4.7 & 2.6 & 0.166 & 0.165 & 0.183 & 7.75 & 9.32 & 11.4 & 0 & 0.18 & 0.21 & 59.07 & 58.07 & 64.6 & 60.67 & 58 & 65 & 66 \\
\hline Kenya & 3.0 & 4.8 & 5.7 & 0.028 & 0.108 & 0.115 & 0 & 13.2 & 5.48 & 0 & 0.01 & 0.04 & 34.09 & 54.07 & 59.04 & 60.45 & 107 & 73 & 67 \\
\hline New Zealand & 6.0 & 3.8 & 3.9 & 0.356 & 0.611 & 0.51 & 3.38 & 1.13 & 1.98 & 0.1 & 0.36 & 0.29 & 69.26 & 52.5 & 57.83 & 60.4 & 33 & 78 & 68 \\
\hline Egypt, A & 5.6 & 6.9 & 16.4 & 0.035 & 0.163 & 0.144 & 0 & 0.76 & 0.48 & 0.02 & 0.28 & 0.27 & 40.24 & 49.8 & 56.34 & 58.19 & 97 & 85 & 69 \\
\hline Albania & 9.6 & 7.6 & 8.6 & 0.192 & 0.974 & 0.532 & 11.1 & 0.04 & 0.63 & 0.12 & 0.34 & 0.11 & 72.44 & 49.91 & 61.18 & 58.18 & 28 & 84 & 70 \\
\hline Uganda & 3.9 & 2.8 & 8.3 & 0 & 0.056 & 0.012 & & 9.53 & 27.5 & 0 & 0 & 0 & 14.68 & 48.16 & 51.83 & 58 & 139 & 89 & 71 \\
\hline United K & 4.5 & 11.4 & 7.7 & 0.15 & 0.067 & 0.031 & 0 & 1.61 & 5.36 & 0.01 & 0 & 0 & 41.55 & 49.28 & 56.41 & 57.53 & 95 & 86 & 72 \\
\hline New Caledonia & 42.2 & 36.6 & 39.0 & 15.62 & 22.05 & 14.43 & 0.51 & 0.41 & 0.35 & 0 & 0 & 0 & 61.41 & 55.3 & 56.42 & 56.71 & 54 & 70 & 73 \\
\hline United States & 4.2 & 6.2 & 5.6 & 0.489 & 0.646 & 0.418 & 0.64 & 0.71 & 0.69 & 0.22 & 0.31 & 0.2 & 65.59 & 53.87 & 57.28 & 56.61 & 43 & 75 & 14 \\
\hline Montenegro & & 32.1 & 31.9 & & 1.465 & 1.258 & & 0 & 0 & 0 & 0.38 & 0.41 & 0.42 & 53.66 & 56.8 & 56.34 & 211 & 77 & 75 \\
\hline Rwanda & 2.8 & 44.6 & 45.3 & 0.14 & 1.554 & 1.004 & 0 & 0.04 & 0 & 0 & 0.39 & 0.23 & 36.64 & 60.91 & 62.57 & 56.29 & 101 & 58 & 76 \\
\hline Israel & 31.9 & 31.2 & 27.2 & 0.213 & 0.588 & 0.52 & 0 & 0 & 0.03 & 0 & 0.05 & 0.06 & 34.31 & 45.68 & 50.01 & 56.2 & 106 & 99 & 77 \\
\hline Cuba & 15.8 & 17.4 & 9.4 & 0.245 & 0.312 & 0.183 & 5.38 & 0 & 0.36 & 0.2 & 0.56 & 0.31 & 73.79 & 45.71 & 57.69 & 55.92 & 25 & 97 & 78 \\
\hline Azerbaijan & 1.6 & 1.0 & 5.2 & 0 & 0.052 & 0.065 & & 2.4 & 1.49 & 0 & 0.08 & 0.2 & 9.911 & 39.87 & 46.29 & 55.86 & 155 & 110 & 79 \\
\hline Bosnia and $\mathrm{H}$ & 6.8 & 10.8 & 9.5 & 0.557 & 3.068 & 2.765 & 0 & 0.08 & 0 & 0.04 & 0.9 & 0.57 & 52.76 & 61.22 & 55.21 & 55.53 & 72 & 57 & 80 \\
\hline Greece & 6.8 & 7.9 & 8.7 & 0.993 & 1.67 & 0.915 & 0.08 & 0.39 & 0.2 & 0.02 & 0.17 & 0.06 & 63.6 & 56.25 & 58.07 & 55.5 & 48 & 68 & 81 \\
\hline Jordan & 21.2 & 7.9 & 9.0 & 0.864 & 1.463 & 1.84 & 0 & 0 & 0 & 0 & 0.96 & 1.25 & 39.35 & 50.12 & 55.12 & 55.09 & 98 & 82 & 82 \\
\hline Myanma & 7.9 & 19.4 & 6.1 & 0.032 & 0.476 & 0.572 & 26.3 & 0.32 & 0.09 & 0 & 0.62 & 0.55 & 46.42 & 54.77 & 58.73 & 54.46 & 85 & 71 & 83 \\
\hline Iran, Islami & 1.4 & 5.4 & 4.6 & 0.099 & 0.453 & 0.357 & 0.04 & 0.54 & 0.44 & 0.09 & 0.77 & 0.42 & 46.94 & 51.52 & 57.52 & 54.36 & 81 & 81 & 84 \\
\hline Oman & 1.5 & 4.8 & 5.2 & 0.011 & 0.194 & 0.098 & 0 & 3.73 & 1.58 & 0 & 0.09 & 0.02 & 12.95 & 53.85 & 61.38 & 54.12 & 144 & 76 & 85 \\
\hline Poland & 11.4 & 5.3 & 4.1 & 2.02 & 1.535 & 1.135 & 0 & 0.13 & 0.1 & 0.54 & 0.61 & 0.54 & 64 & 53.87 & 56.92 & 54.09 & 47 & 74 & 86 \\
\hline Mal & 1.4 & 3.1 & 4.2 & 0.058 & 0.18 & 0.093 & 3.8 & 0.9 & 1.12 & 0.06 & 0.28 & 0.19 & 54.47 & 45.7 & 54.92 & 54.05 & 68 & 98 & 87 \\
\hline Burundi & 32.3 & 41.6 & 44.4 & 0 & 0.524 & 0.243 & & 0 & 0 & 0.36 & 0.45 & 0.5 & 44.22 & 50.04 & 55.9 & 53.6 & 88 & 83 & 88 \\
\hline
\end{tabular}




\begin{tabular}{|c|c|c|c|c|c|c|c|c|c|c|c|c|c|c|c|c|c|c|c|}
\hline Panama & 2.7 & 5.1 & 2.4 & 0.039 & 0 & 0.001 & 116 & & 639 & 0 & 0 & 0.04 & 43.77 & 24.57 & 45.32 & 52.3 & 89 & 129 & 89 \\
\hline Norway & 7.1 & 5.5 & 6.3 & 0.082 & 0.16 & 0.075 & 0 & 0.72 & 0.99 & 0 & 0.04 & 0.02 & 41.43 & 45.48 & 50.26 & 51.46 & 96 & 100 & 90 \\
\hline Malawi & 0.2 & 1.5 & 1.5 & 0.032 & 0.031 & 0.016 & 0 & 98.6 & 50.1 & 0 & 0.04 & 0.04 & 9.575 & 46.92 & 56.24 & 51.21 & 156 & 94 & 91 \\
\hline Sri Lanka & 6.1 & 3.8 & 2.4 & 0.025 & 0.019 & 0.012 & 0.47 & 18.7 & 23.7 & 0 & 0 & 0 & 34.85 & 48.73 & 51.79 & 50.61 & 104 & 88 & 92 \\
\hline Uruguay & 0.9 & 1.3 & 1.1 & 0 & 0.105 & 0.062 & & 5.47 & 3.52 & 0 & 0.09 & 0.09 & 7.352 & 47.18 & 31.09 & 50.49 & 166 & 92 & 93 \\
\hline China & 3.1 & 1.5 & 1.4 & 2.067 & 2.356 & 1.533 & 0.01 & 0.15 & 0.13 & 0.22 & 1.9 & 0.73 & 65.2 & 51.77 & 51.22 & 50.43 & 45 & 80 & 94 \\
\hline Portugal & 1.7 & 2.7 & 2.4 & 0.112 & 0.215 & 0.18 & 0.86 & 4.12 & 0.99 & 0 & 0.15 & 0.13 & 33.55 & 52.33 & 54.82 & 50.11 & 109 & 79 & 95 \\
\hline Ireland & 1.2 & 1.4 & 0.9 & 0.118 & 0.213 & 0.083 & 1.82 & 4.71 & 4.29 & 0.01 & 0.07 & 0.04 & 50.33 & 48.03 & 49.65 & 50.02 & 78 & 90 & 96 \\
\hline Kosovo & & & & - & 3.635 & 3.329 & & 0 & 0.27 & 0 & 1.24 & 0.68 & 0.42 & 40.01 & 50.89 & 50.02 & 212 & 109 & 97 \\
\hline Saudi Arabia & 0.8 & 1.1 & 2.4 & 0.014 & 0.034 & 0.074 & 1.74 & 11.1 & 1.46 & 0 & 0.05 & 0.08 & 26.78 & 44.94 & 56.24 & 49.97 & 114 & 101 & 98 \\
\hline Cambodia & 0.3 & 1.4 & $9.3-$ & & - & 0.027 & & & 97.3 & 0 & 0 & 0 & 4.606 & 5.13 & 36.01 & 48.89 & 185 & 190 & 95 \\
\hline Spain & 2.5 & 3.9 & 3.8 & 0.158 & 0.142 & 0.119 & 0.57 & 0.86 & 0.8 & 0 & 0.04 & 0.03 & 52.11 & 43.86 & 50.19 & 48.8 & 74 & 102 & 100 \\
\hline Cameroon & 5.5 & 3.9 & 6.3 & 0 & 0.038 & 0.055 & & & 0.23 & 0.01 & 0.12 & 0.13 & 33.6 & 31.54 & 53.06 & 48.55 & 108 & 121 & 101 \\
\hline Yemen, Rep. & 0.6 & 1.6 & $30.6-$ & & - & 0.006 & & & 2.61 & 0 & 0 & 0 & 5.653 & 5.821 & 44.85 & 48.26 & 177 & 188 & 102 \\
\hline Thailand & 3.0 & 3.8 & 4.8 & 0.185 & 0.2 & 0.157 & 0.17 & 0.06 & 0.13 & 0.03 & 0.09 & 0.06 & 53.53 & 39.38 & 45.66 & 46.56 & 70 & 111 & 103 \\
\hline Cyprus & 1.7 & 8.3 & 3.7 & 0.014 & 0.071 & 0.047 & 0 & 8.97 & 0.8 & 0.01 & 0.07 & 0.03 & 31.39 & 58.35 & 53.89 & 46.36 & 110 & 62 & 104 \\
\hline Nauru & 73.2 & 83.3 & $72.1-$ & & 7.985 & 5.204 & 0 & 0 & 0 & 0 & 0 & 0 & 24.84 & 47.52 & 47.38 & 46.23 & 116 & 91 & 105 \\
\hline Romania & 3.4 & 2.7 & 2.0 & 0.815 & 0.567 & 0.407 & 0 & 0.38 & 0.53 & 0.15 & 0.05 & 0.04 & 52.32 & 41.26 & 47.65 & 46.04 & 73 & 106 & 106 \\
\hline Vietnam & 2.0 & 1.4 & 1.5 & 0.301 & 0.847 & 0.611 & 0.52 & 0.08 & 0.07 & 0.03 & 0.7 & 0.4 & 55.9 & 41.66 & 48.47 & 45.64 & 63 & 105 & 107 \\
\hline Japan & 1.4 & 3.4 & 3.7 & 0.015 & 0.008 & 0.009 & 1.65 & 2.27 & 1.44 & 0 & 0 & 0 & 43.73 & 41.25 & 44.28 & 45.46 & 90 & 107 & 108 \\
\hline Bhutan & 4.0 & 16.5 & 12.0 & 0.174 & 0.171 & 0.185 & 0 & 0 & 0 & 0.22 & 0.08 & 0.11 & 46.47 & 40.59 & 45.1 & 45.13 & 84 & 108 & 109 \\
\hline Czech $\operatorname{Re}$ & 4.9 & 2.6 & 1.7 & 1.654 & 1.271 & 0.907 & 0.03 & 0.01 & 0.01 & 0.26 & 0.12 & 0.1 & 66.89 & 43.15 & 45.39 & 43.9 & 40 & 104 & 110 \\
\hline Switzerland & 5.1 & 27.0 & 29.5 & 0.004 & 0.004 & 0.005 & 0 & 1.68 & 1.25 & 0 & 0 & 0 & 18.52 & 37.23 & 40.54 & 43.78 & 133 & 113 & 111 \\
\hline Ethiopia & 0.4 & 3.7 & 6.3 & 0.101 & 0.305 & 0.205 & 2.67 & 4.51 & 0 & 0.04 & 0.57 & 0.35 & 50.33 & 58.2 & 68.13 & 43.62 & 77 & 64 & 112 \\
\hline Angola & 5.2 & 3.4 & 2.3 & 0.347 & 0.776 & 0.628 & 0.24 & 4.81 & 2.56 & 0 & 0 & 0 & 42.2 & 43.37 & 46 & 43.22 & 94 & 103 & 113 \\
\hline Slovak Republic & 5.4 & 2.5 & 1.9 & 0.225 & 0.114 & 0.089 & 1.81 & 4.21 & 0.64 & 0.01 & 0.02 & 0.03 & 61.34 & 47.12 & 47.55 & 43.02 & 55 & 93 & 114 \\
\hline Djibouti & 6.1 & 3.3 & $11.7-$ & & & & & & 4800 & 0 & 0 & 0 & 16.82 & 10.2 & 18.6 & 41.5 & 136 & 165 & 115 \\
\hline Korea, Rep. & 5.0 & 2.2 & 2.3 & 0.056 & 0.031 & 0.028 & 0 & 0.54 & 0.49 & 0 & 0.01 & 0 & 38.82 & 32.87 & 42.27 & 39.49 & 99 & 118 & 116 \\
\hline Swaziland & 1.6 & 4.6 & 5.2 & 0.079 & 0.556 & 0.098 & 86.8 & 0.36 & 0 & 0.23 & 0.15 & 0.13 & 63.12 & 46 & 37.99 & 39.49 & 49 & 96 & 117 \\
\hline Pakistan & 0.3 & 1.8 & 1.5 & 0.038 & 0.07 & 0.069 & 1.96 & 0.13 & 0.14 & 0.06 & 0.08 & 0.05 & 46.53 & 32.85 & 40.12 & 38.02 & 83 & 119 & 11 \\
\hline
\end{tabular}




\begin{tabular}{|c|c|c|c|c|c|c|c|c|c|c|c|c|c|c|c|c|c|c|c|}
\hline Slovenia & 3.4 & 3.7 & 4.6 & 0.511 & 0.428 & 0.348 & 0 & 0 & 0 & 0.01 & 0.02 & 0.02 & 47.2 & 32.57 & 36.98 & 37.65 & 80 & 120 & 119 \\
\hline Tunisia & 1.7 & 1.8 & 1.6 & 0.433 & 0.297 & 0.3 & 0 & 1.31 & 0 & 0.01 & 0.41 & 0.5 & 42.22 & 46 & 47.37 & 37 & 93 & 95 & 120 \\
\hline Paraguay & 0.4 & 1.1 & $1.4-$ & & - & 0.002 & & & 161 & 0 & 0 & 0 & 4.839 & 3.747 & 34.9 & 35.83 & 184 & 198 & 121 \\
\hline France & 2.6 & 2.5 & 2.3 & 0.044 & 0.022 & 0.016 & 0.42 & 0.47 & 0.25 & 0 & 0 & 0 & 46.62 & 31.25 & 36.7 & 35.51 & 82 & 122 & 122 \\
\hline Italy & 1.3 & 3.0 & 2.9 & 0.015 & 0.031 & 0.025 & 1.2 & 0.09 & 0.08 & 0 & 0 & 0 & 42.26 & 29.98 & 37.77 & 35.33 & 92 & 123 & 123 \\
\hline Germany & 2.6 & 3.1 & 2.7 & 0.365 & 0.503 & 0.388 & 0 & 0.06 & 0 & 0.02 & 0.02 & 0.01 & 44.71 & 36.5 & 41.76 & 34.7 & 87 & 116 & 124 \\
\hline Venezuela, RB & 6.0 & 1.7 & 4.2 & 0.272 & 0.125 & 0.153 & 2.36 & 0.16 & 0.29 & 0.28 & 0.36 & 0 & 68.82 & 36.76 & 32.76 & 33.07 & 34 & 115 & 125 \\
\hline Austria & 3.0 & 3.6 & 3.5 & 0.047 & 0.103 & 0.073 & 0 & 0.41 & 0 & 0 & 0.03 & 0.01 & 34.93 & 38.5 & 40.06 & 32.49 & 103 & 112 & 126 \\
\hline Belarus & 1.0 & 0.9 & 1.2 & 0.519 & 2.273 & 2.718 & 0 & 0.11 & 0.09 & 0 & 0 & 0 & 24.78 & 27.61 & 31.14 & 32.09 & 117 & 126 & 127 \\
\hline Benin & 0.6 & 11.9 & $25.8-$ & & - & 0 & & & & 0 & 0.01 & 0.01 & 6.118 & 29.87 & 30.56 & 31.78 & 174 & 124 & 128 \\
\hline Iraq & 0.2 & 0.4 & 4.6 & 0.014 & 0.023 & 0.017 & 0 & 0 & 0 & 0 & 0 & 0 & 7.552 & 15.77 & 11.19 & 31.32 & 164 & 152 & 129 \\
\hline Nigeria & 0.2 & 0.7 & 2.0 & 0.008 & 0.022 & 0.048 & 0 & 0.09 & 0 & 0 & 0.04 & 0.07 & 21.75 & 24.97 & 26.52 & 31.05 & 125 & 127 & 130 \\
\hline Central A & 56.0 & 39.1 & 8.7 & 1.473 & 2.658 & 0 & 0 & 0 & & 0.01 & 0.1 & 0.1 & 60.8 & 55.93 & 36.7 & 30.62 & 56 & 69 & 131 \\
\hline Chad & 0.1 & 0.1 & $12.5-$ & & - & 0 & & & & 0 & 0.02 & 0.03 & 3.095 & 13.58 & 14.25 & 30.54 & 195 & 156 & 132 \\
\hline Hungary & 4.3 & 1.7 & 1.3 & 0.414 & 0.329 & 0.237 & 0 & 0.32 & 0 & 0.03 & 0.01 & 0.01 & 48.76 & 34.95 & 30.26 & 29.58 & 79 & 117 & 133 \\
\hline Luxembo & 6.4 & 8.3 & 6.0 & 0 & 0 & 0 & & & & 0 & 0.03 & 0.05 & 17.24 & 29.63 & 28.35 & 27 & 135 & 125 & 134 \\
\hline Croatia & 2.2 & 4.7 & 3.2 & 0.004 & 0 & 0.004 & 0 & & 0 & 0 & 0 & 0 & 29.07 & 23.78 & 17.42 & 26.81 & 113 & 132 & 135 \\
\hline Costa Rica & 1.3 & 1.1 & 1.1 & 0.025 & 0 & 0.054 & 170 & & 0 & 0 & 0.02 & 0.02 & 38.21 & 16.54 & 27 & 26.57 & 100 & 150 & 136 \\
\hline Nepal & 0.1 & 3.9 & 3.0 & 0 & 0.001 & $8 \mathrm{E}-04$ & & 0 & 0 & 0 & 0 & 0 & 2.934 & 24.31 & 24.79 & 26.1 & 197 & 131 & 137 \\
\hline Algeria & 0.6 & 0.2 & 0.3 & 0.034 & 0.029 & 0.036 & 0 & 0 & 0 & 0.03 & 0.06 & 0.07 & 29.8 & 18.31 & 26.47 & 25.65 & 111 & 141 & 138 \\
\hline Lebanon & 10.6 & 19.1 & $22.3-$ & & - & $9 \mathrm{E}-04$ & & & 0 & 0 & 0 & 0 & 19.61 & 19.53 & 25.81 & 25.53 & 130 & 137 & 139 \\
\hline Netherland & 2.9 & 2.9 & 2.8 & 0.021 & 0.039 & 0.041 & 0 & 0 & 0.03 & 0 & 0 & 0 & 17.87 & 13.51 & 18.97 & 24.62 & 134 & 158 & 140 \\
\hline French Polynesia & 71.0 & 68.2 & $64.9-$ & & - & - & & & & 0 & 0 & 0 & 24.61 & 24.6 & 24.47 & 24.34 & 118 & 128 & 141 \\
\hline Bangladesh & 0.0 & 0.5 & 0.4 & $5 E-04$ & 0.03 & 0.026 & 0 & 0 & 0 & 0 & 0.02 & 0.01 & 4.143 & 18.12 & 23.39 & 23.41 & 189 & 144 & 142 \\
\hline Korea, Dem. People's Rep. & 10.8 & 49.1 & $52.7-$ & & - & - & 0 & 0 & 0 & 0 & 0 & 0 & 19.84 & 23.22 & 23.54 & 23.41 & 128 & 133 & 143 \\
\hline Denmark & 1.0 & 1.6 & 1.3 & 0.007 & 0.01 & 0.011 & 0 & 0 & 0 & 0 & 0 & 0 & 10.52 & 7.88 & 12.37 & 23.21 & 153 & 176 & 144 \\
\hline French Guyana & & & & - & - & & 31.5 & 25.2 & 6.71 & 0 & 0 & 0 & 23.47 & 24.49 & 23.89 & 23.1 & 121 & 130 & 145 \\
\hline Montserrat & 0.2 & 25.3 & $38.7-$ & & - & & & & & 0 & 0 & 0 & 3.327 & 20.22 & 19.76 & 21.8 & 193 & 135 & 146 \\
\hline Belgium & 9.6 & 7.5 & 7.0 & 0.011 & 0.008 & 0.01 & 0 & 0 & 0 & 0 & 0 & 0 & 22.18 & 17.08 & 22.38 & 21.75 & 124 & 146 & 147 \\
\hline Iceland & 10.6 & 39.0 & $36.4-$ & & - & 0 & & & & 0 & 0 & 0 & 19.72 & 22.41 & 22.52 & 21.45 & 129 & 134 & 14 \\
\hline
\end{tabular}




\begin{tabular}{|c|c|c|c|c|c|c|c|c|c|c|c|c|c|c|c|c|c|c|}
\hline United Arab Emirates & 4.2 & 13.2 & $26.9-$ & - & 0 & & & & 0 & 0 & 0 & 14.96 & 18.26 & 18.95 & 20.06 & 138 & 142 & 149 \\
\hline Bahrain & 42.3 & 24.6 & $22.7-$ & - & - & & & & 0 & 0 & 0 & 23.44 & 20.11 & 20.1 & 19.58 & 122 & 136 & 150 \\
\hline British Virgin Islands & 36.2 & 12.8 & $19.2-$ & - & - & & & & 0 & 0 & 0 & 22.98 & 18.15 & 18.24 & 18.76 & 123 & 143 & 151 \\
\hline Somalia & 0.0 & 10.3 & $18.9-$ & - & - & & & & 0 & 0 & 0 & 1.932 & 17.23 & 16.52 & 18.65 & 204 & 145 & 152 \\
\hline Northern Mariana Islands & 3.3 & 13.6 & $18.6-$ & - & - & & & & 0 & 0 & 0 & 13.91 & 18.38 & 17.21 & 18.53 & 141 & 140 & 153 \\
\hline \multicolumn{2}{|c|}{ Bonaire, Sint Eustatius and Saba } & 2.5 & $16.8-$ & - & & & & 0 & 0 & 0 & 0 & 0.42 & 8.125 & 20.34 & 18.43 & 213 & 173 & 154 \\
\hline Libya & 0.0 & 2.3 & $17.2-$ & - & - & & & 0 & 0 & 0 & 0 & 1.583 & 7.664 & 16.91 & 18.41 & 206 & 178 & 155 \\
\hline Hong Kong SAR, China & 2.5 & 14.7 & $15.4-$ & - & 0 & & & & 0 & 0 & 0 & 11.93 & 18.49 & 17.8 & 17.97 & 146 & 139 & 156 \\
\hline Sint Maarten (Dutch part) & & 3.1 & $14.6-$ & - & - & & & & 0 & 0 & 0 & 0.42 & 9.623 & 19.74 & 17.72 & 214 & 169 & 157 \\
\hline Aruba & 0.6 & 2.3 & $14.0-$ & - & - & & & & 0 & 0 & 0 & 6.234 & 7.895 & 8.106 & 17.48 & 173 & 175 & 158 \\
\hline American Samoa & 0.0 & 3.8 & $12.4-$ & - & - & & & & 0 & 0 & 0 & 0.42 & 11.58 & 11.68 & 17.13 & 215 & 161 & 159 \\
\hline Cayman Islands & 5.0 & 0.9 & $10.3-$ & - & - & & & & 0 & 0 & 0 & 15.77 & 3.171 & 2.807 & 16.32 & 137 & 201 & 160 \\
\hline State of Palestine & 0.0 & 9.1 & $8.8-$ & - & & & & & 0 & 0 & 0 & 0.42 & 16.77 & 16.3 & 15.64 & 216 & 148 & 161 \\
\hline Equatorial Guinea & 0.0 & 0.0 & $0.1-$ & - & 0 & & & & 0 & 0.03 & 0.06 & 1.467 & 13.8 & 14.57 & 15.46 & 207 & 155 & 162 \\
\hline China, Macao SAR & 0.4 & 5.7 & $8.4-$ & - & 0 & & & & 0 & 0 & 0 & 5.188 & 13.89 & 15.15 & 15.18 & 181 & 154 & 163 \\
\hline Grenada & 0.2 & 10.1 & $8.2-$ & - & 0 & & & & 0 & 0 & 0 & 3.676 & 17 & 16.88 & 14.94 & 192 & 147 & 164 \\
\hline Gambia, The & 67.7 & 8.7 & $8.2-$ & - & 0 & & & & 0 & 0 & 0 & 24.37 & 16.42 & 17.46 & 14.83 & 120 & 151 & 165 \\
\hline Dominica & 1.7 & 7.5 & $6.9-$ & - & & & & 0 & 0 & 0 & 0 & 9.955 & 15.15 & 15.04 & 14.24 & 154 & 153 & 166 \\
\hline Latvia & 1.1 & 3.3 & $2.1-$ & - & 0.005 & & & 0 & 0 & 0 & 0 & 7.978 & 10.08 & 15.61 & 13.29 & 161 & 166 & 167 \\
\hline Moldova & 1.4 & 1.8 & $1.1-$ & - & 0.018 & & & 0 & 0 & 0 & 0 & 9.025 & 6.397 & 14.63 & 12.25 & 159 & 186 & 168 \\
\hline Turkmenistan & 1.0 & 0.5 & $1.0-$ & - & 0.013 & & & 0 & 0 & 0 & 0 & 7.746 & 2.48 & 11.96 & 11.59 & 162 & 206 & 169 \\
\hline El Salvador & 1.4 & 2.0 & $1.3-$ & - & 0.01 & & & 0 & 0 & 0 & 0 & 9.257 & 7.088 & 13.03 & 11.5 & 157 & 182 & 170 \\
\hline St. Lucia & 0.2 & 3.5 & $4.4-$ & - & 0 & & & & 0 & 0 & 0 & 3.211 & 10.89 & 7.662 & 11.34 & 194 & 162 & 171 \\
\hline Mauritius & 1.9 & 5.4 & $4.3-$ & - & 0 & & & & 0 & 0 & 0 & 10.89 & 13.54 & 13.42 & 11.22 & 150 & 157 & 172 \\
\hline Guam & 0.0 & 8.7 & $4.1-$ & - & - & & & & 0 & 0 & 0 & 0.42 & 16.65 & 15.59 & 10.62 & 217 & 149 & 173 \\
\hline Syrian Arab Republic & 0.9 & 2.2 & $4.1-$ & - & - & 0 & 0 & 0 & 0 & 0 & 0 & 7.048 & 7.319 & 6.493 & 10.51 & 168 & 180 & 174 \\
\hline Andorra & 3.2 & 5.0 & $3.9-$ & - & - & & & & 0 & 0 & 0 & 13.56 & 12.96 & 12.71 & 10.27 & 143 & 159 & 175 \\
\hline Tonga & 0.4 & 3.2 & $3.8-$ & - & 0 & & & & 0 & 0 & 0 & 5.071 & 9.853 & 9.967 & 9.942 & 182 & 168 & 176 \\
\hline Kuwait & 0.9 & 0.4 & $0.9-$ & - & $9 \mathrm{E}-04$ & & & 0 & 0 & 0 & 0 & 7.281 & 2.019 & 8.972 & 9.461 & 167 & 209 & 177 \\
\hline \multicolumn{2}{|c|}{ St. Vincent and the Grenadines0.1 } & 3.4 & $3.4-$ & - & 0 & & & & 0 & 0 & 0 & 2.63 & 10.54 & 9.851 & 9.361 & 199 & 163 & 178 \\
\hline
\end{tabular}




\begin{tabular}{|c|c|c|c|c|c|c|c|c|c|c|c|c|c|c|c|c|c|c|}
\hline Turks and Caicos Islands & 0.1 & 3.3 & $3.4-$ & - & - & & & & 0 & 0 & 0 & 2.862 & 10.31 & 11.22 & 9.343 & 198 & 164 & 179 \\
\hline Trinidad and Tobago & 1.0 & 1.5 & $3.0-$ & - & 0 & & & & 0 & 0 & 0 & 7.397 & 5.476 & 4.782 & 9.012 & 165 & 189 & 180 \\
\hline Palau & 0.6 & 2.5 & $2.8-$ & - & 0 & & & & 0 & 0 & 0 & 6.467 & 8.471 & 5.704 & 8.78 & 172 & 172 & 181 \\
\hline Singapore & 2.1 & 2.0 & $2.5-$ & - & 0 & & & & 0 & 0 & 0 & 11.35 & 7.204 & 7.317 & 8.315 & 148 & 181 & 182 \\
\hline Anguilla & 0.1 & 3.2 & $2.5-$ & - & & & & & 0 & 0 & 0 & 2.513 & 9.969 & 10.2 & 8.198 & 200 & 167 & 183 \\
\hline China, Taiwan Province of & 1.3 & 2.3 & $2.5-$ & - & & 0 & 0 & 0 & 0 & 0 & 0 & 8.444 & 7.78 & 7.893 & 8.082 & 160 & 177 & 184 \\
\hline Comoros & 0.0 & 3.0 & $2.4-$ & - & 0 & & & & 0 & 0 & 0 & 1.816 & 9.277 & 9.621 & 7.733 & 205 & 170 & 185 \\
\hline Qatar & 0.3 & 1.2 & $2.4-$ & - & 0 & & & & 0 & 0 & 0 & 4.141 & 4.439 & 8.584 & 7.501 & 190 & 194 & 186 \\
\hline Estonia & 2.9 & 2.4 & $2.2-$ & - & 0 & & & & 0 & 0 & 0 & 12.75 & 8.01 & 7.202 & 6.803 & 145 & 174 & 187 \\
\hline Bahamas, The & 15.4 & 1.9 & 2.20 .343 & 0.762 & 0 & 0 & 0 & & 0 & 0 & 0 & 34.63 & 18.57 & 22.72 & 6.687 & 105 & 138 & 188 \\
\hline Cook Islands & 27.0 & 1.9 & $2.0-$ & - & & & & & 0 & 0 & 0 & 21.7 & 6.628 & 6.856 & 6.222 & 126 & 185 & 189 \\
\hline Maldives & 0.3 & 1.9 & $1.8-$ & - & 0 & & & & 0 & 0 & 0 & 3.909 & 6.743 & 5.128 & 5.989 & 191 & 184 & 190 \\
\hline Haiti & 0.6 & 1.9 & $1.5-$ & 0 & 0 & & & & 0 & 0 & 0 & 5.885 & 7.039 & 6.05 & 5.408 & 176 & 183 & 191 \\
\hline Sao Tome and Principe & 1.8 & 1.2 & $1.4-$ & - & 0 & & & & 0 & 0 & 0 & 10.54 & 4.554 & 4.321 & 5.059 & 152 & 193 & 192 \\
\hline Barbados & 2.1 & 2.2 & $1.4-$ & - & 0 & & & & 0 & 0 & 0 & 11.23 & 7.434 & 5.819 & 4.942 & 149 & 179 & 193 \\
\hline Cabo Verde & 1.8 & 1.6 & $1.3-$ & - & 0 & & & & 0 & 0 & 0 & 10.77 & 5.936 & 3.169 & 4.71 & 151 & 187 & 194 \\
\hline Lithuania & 2.5 & 1.4 & $1.3-$ & - & 0 & & & & 0 & 0 & 0 & 11.82 & 4.899 & 4.552 & 4.361 & 147 & 191 & 195 \\
\hline Tokelau & 0.3 & 3.9 & $0.9-$ & - & & & & & 0 & 0 & 0 & 4.257 & 12.04 & 13.19 & 3.315 & 188 & 160 & 196 \\
\hline Antigua and Barbuda & 9.6 & 0.8 & $0.8-$ & - & 0 & & & & 0 & 0 & 0 & 18.91 & 3.056 & 5.473 & 3.198 & 131 & 202 & 197 \\
\hline Timor-Leste & & 0.2 & $0.8-$ & - & 0 & & & & 0 & 0 & 0 & 0.42 & 1.213 & 1.556 & 3.082 & 218 & 215 & 198 \\
\hline Malta & 0.6 & 0.7 & $0.8-$ & - & 0 & & & & 0 & 0 & 0 & 5.537 & 2.941 & 3.054 & 2.966 & 178 & 203 & 199 \\
\hline Seychelles & 0.3 & 0.9 & $0.6-$ & - & 0 & & & & 0 & 0 & 0 & 4.49 & 3.402 & 2.017 & 2.733 & 186 & 200 & 200 \\
\hline Bermuda & 0.1 & 1.2 & $0.6-$ & - & - & & & & 0 & 0 & 0 & 2.978 & 4.323 & 3.728 & 2.715 & 196 & 195 & 201 \\
\hline Belize & 0.4 & 1.1 & $0.6-$ & - & 0 & & & & 0 & 0 & 0 & 5.304 & 4.093 & 5.589 & 2.617 & 180 & 197 & 202 \\
\hline Samoa & 0.4 & 1.1 & $0.5-$ & - & 0 & & & & 0 & 0 & 0 & 4.955 & 3.632 & 6.395 & 2.501 & 183 & 199 & 203 \\
\hline Brunei Darussalam & 0.0 & 0.5 & $0.5-$ & - & 0 & & & & 0 & 0 & 0 & 2.048 & 2.365 & 2.363 & 2.384 & 203 & 207 & 204 \\
\hline Gibraltar & 18.5 & 0.6 & $0.4-$ & - & - & & & & 0 & 0 & 0 & 21 & 2.711 & 2.691 & 2.134 & 127 & 204 & 205 \\
\hline Tuvalu & 0.0 & 1.3 & $0.3-$ & - & 0 & & & & 0 & 0 & 0 & 0.42 & 4.784 & 6.741 & 2.035 & 219 & 192 & 206 \\
\hline St. Kitts and Nevis & 0.0 & 0.2 & $0.3-$ & - & 0 & & & & 0 & 0 & 0 & 1.234 & 1.558 & 1.787 & 1.919 & 209 & 212 & 207 \\
\hline Guinea-Bissau & 0.1 & 0.4 & $0.3-$ & - & 0 & & & & 0 & 0 & 0 & 2.164 & 1.904 & 1.902 & 1.803 & 202 & 210 & 208 \\
\hline
\end{tabular}

\begin{tabular}{|c|c|c|c|c|c|c|c|c|c|c|c|c|c|c|c|c|c|c|}
\hline Vanuatu & 0.4 & 0.3 & $0.3-$ & - & 0 & & & & 0 & 0 & 0 & 5.42 & 1.674 & 1.211 & 1.687 & 179 & 211 & 209 \\
\hline Micronesia, Fed. Sts. & 0.0 & 0.2 & $0.2-$ & - & 0 & & & & 0 & 0 & 0 & 1.351 & 1.443 & 1.672 & 1.454 & 208 & 213 & 210 \\
\hline Greenland & 0.0 & 2.8 & $0.1-$ & - & - & & & & 0 & 0 & 0 & 1.118 & 9.047 & 8.797 & 1.203 & 210 & 171 & 211 \\
\hline Marshall Islands & 0.9 & 0.5 & $0.1-$ & - & 0 & & & & 0 & 0 & 0 & 6.932 & 2.134 & 2.478 & 0.989 & 169 & 208 & 212 \\
\hline Faroe Islands & 0.0 & 0.2 & $0.1-$ & - & - & & & & 0 & 0 & 0 & 0.42 & 1.328 & 1.309 & 0.971 & 220 & 214 & 213 \\
\hline Saint Helena & 0.7 & 1.2 & $0.1-$ & - & & & & & & & & 6.583 & 4.208 & 0.75 & 0.873 & 170 & 196 & 214 \\
\hline Kiribati & 1.0 & 0.1 & $0.0-$ & - & 0 & & & & 0 & 0 & 0 & 7.63 & 0.982 & 1.326 & 0.756 & 163 & 216 & 215 \\
\hline Niue & 0.6 & 0.6 & $0.0-$ & - & & & & & 0 & 0 & 0 & 6.002 & 2.595 & 2.709 & 0.64 & 175 & 205 & 216 \\
\hline Falkland Islands (Malvinas) & 0.3 & 0.0 & $0.0-$ & - & & & & & 0 & 0 & 0 & 4.374 & 0.637 & 0.635 & 0.524 & 187 & 217 & 217 \\
\hline Western Sahara & 86.7 & & - & - & & & & & 0 & 0 & 0 & 25.3 & 0.406 & 0.52 & 0.408 & 115 & 219 & 218 \\
\hline Netherlands Antilles & 3.2 & & - & - & & & & & 0 & 0 & 0 & 13.79 & 0.406 & 0.52 & 0.408 & 142 & 220 & 219 \\
\hline St. Martin (French part) & 0.1 & 0.0 & - & - & & & & & 0 & 0 & 0 & 2.397 & 0.522 & 0.865 & 0.408 & 201 & 218 & 220 \\
\hline Wallis and Futuna Islands & 0.0 & 0.0 & - & - & & & & & 0 & 0 & 0 & 0.42 & 0.406 & 0.52 & 0.408 & 221 & 231 & 231 \\
\hline Christmas Island & & & - & - & & 0 & 0 & 0 & 0 & 0 & 0 & 0.42 & 0.406 & 0.52 & 0.408 & 222 & 222 & 222 \\
\hline Channel Islands & & & - & - & & & & & 0 & 0 & 0 & 0.42 & 0.406 & 0.52 & 0.408 & 223 & 221 & 221 \\
\hline Curacao & & & - & - & & & & & 0 & 0 & 0 & 0.42 & 0.406 & 0.52 & 0.408 & 224 & 223 & 223 \\
\hline Isle of Man & & & - & - & & & & & 0 & 0 & 0 & 0.42 & 0.406 & 0.52 & 0.408 & 225 & 224 & 224 \\
\hline Liechtenstein & & & - & - & & & & & 0 & 0 & 0 & 0.42 & 0.406 & 0.52 & 0.408 & 226 & 225 & 225 \\
\hline Monaco & & & - & - & & & & & 0 & 0 & 0 & 0.42 & 0.406 & 0.52 & 0.408 & 227 & 226 & 226 \\
\hline Puerto Rico & & & - & - & & & & & 0 & 0 & 0 & 0.42 & 0.406 & 0.52 & 0.408 & 228 & 227 & 227 \\
\hline San Marino & & & - & - & & & & & 0 & 0 & 0 & 0.42 & 0.406 & 0.52 & 0.408 & 229 & 228 & 228 \\
\hline South Sudan & & & - & - & 0 & & & & 0 & 0 & 0 & 0.42 & 0.406 & 0.52 & 0.408 & 230 & 229 & 229 \\
\hline Virgin Islands (U.S.) & & & - & - & & & & & 0 & 0 & 0 & 0.42 & 0.406 & 0.52 & 0.408 & 231 & 230 & 230 \\
\hline
\end{tabular}


Open Access This article is distributed under the terms of the Creative Commons Attribution 4.0 International License (http:// creativecommons.org/licenses/by/4.0/), which permits unrestricted use, distribution, and reproduction in any medium, provided you give appropriate credit to the original author(s) and the source, provide a link to the Creative Commons license, and indicate if changes were made.

\section{References}

Addison T, Roe AR (2018) Extractive industries: the management of resources as a driver of sustainable development. Oxford University Press, Oxford

Atkinson Keen K (2016) Next upswing in metal prices inevitable with few quality mines coming online. S\&P Global Market Intelligence

Bastida AE Editor (2014) Can mining be a catalyst for diversifying economies?, special issue of mineral economics Vol 27, numbers 2-3

Ericsson M, Löf O (2017) Mining's contribution to low- and middleincome economies, WIDER working paper 2017/148

Hailo D, Kipgen C (2017) The Extractive Dependence Index (EDI). Resources Policy 51:251-264

Humphreys D (2015) The remaking of the mining industry. Palgrave MacMillan, Basingstoke

ICMM The role of mining in national economies, 1st edition, 2010, 2nd edition 2014, 3rd edition 2016

ICMM (2018) Social progress in mining-dependent countries

Lange G-M, Wodon Q, and Carey K (2018) The changing wealth of nations 2018, World Bank, pp 11, 75 and 82

McKinsey Global Institute, Bratt M, Dobbs R, Kendall A, van der Marel F, Oppenheim J, Thompson F (2013) Reverse the curse: maximizing the potential of resource-driven economies, December 2013

McMahon G and Moreira S (2014) The contribution of the mining sector to socioeconomic and human development. Extractive industries for development series no. 30, World Bank, Washington, DC

Natural Resources Canada (2001) Overview of trends in Canadian mineral exploration 2000, Canadian Intergovernmental Working Group on the Mineral Industry

Nülle GM, Davis GA (2018) Neither Dutch nor disease? - natural resource booms in theory and empirics. Miner Econ 31:35-59
Otto J (2006) The competitive position of countries seeking exploration and development investment. Journal of the Society of Economic Geologist, Special Publication 12:1-17

Raw Materials Data (2015) database on world mining industry, Stockholm

SNL Metals \& Mining (previously Metals Economics Group, Halifax), Corporate exploration strategies, annual study various years. This study is sometimes also referred to as S\&P Global, Exploration trends

Tercero Espinoza L.,A., and Soulier, M., An examination of copper contained in international trade, Miner Econ, 29:47-56, 2016

UNCTAD (2016) The Iron ore market 2016, Geneva

World Bank Data, mineral rents https://data.worldbank.org/indicator/NY. GDP.MINR.RT.ZS

World Bank/International Bank for Reconstruction and Development (2017) The growing role of minerals and metals for a low carbon future, Washington, DC

Worstall T (2015) Rio Tinto and Vale killed the commodities "super cycle" not China or the Fed, Forbes $29^{\text {th }}$ November 2015

\section{Non-printed sources (various years)}

British Geological Survey

Extractive Industries Transparency Initiative (EITI)

International Labour Organisation, international labour office database on labour statistics (Laborsta) operated by the ILO Department of Statistics

Raw Materials Data

United Nations Conference on Trade and Development (UNCTAD)

US Geological Survey

World Bank

World Mining Data, Federal Ministry of Science, Research and Economy, Austria

Publisher's note Springer Nature remains neutral with regard to jurisdictional claims in published maps and institutional affiliations 